\title{
Intrachain Chromophore Interactions in Silanylene-Spaced Divinylbenzene Copolymers
}

\author{
TSYR-YUAN HWU, ${ }^{1}$ SOURAV BASU, ${ }^{1}$ RUEY-MIN CHEN, ${ }^{1}$ YEN-JU CHENG, ${ }^{1,2}$ JUI-HUNG HSU, \\ WUNSHAIN FANN, ${ }^{3}$ TIEN-YAU LUH ${ }^{1,2}$ \\ ${ }^{1}$ Department of Chemistry, National Taiwan University, Taipei, Taiwan 106 \\ ${ }^{2}$ Institute of Chemistry, Academia Sinica, Nankang, Taipei, Taiwan 115 \\ ${ }^{3}$ Institute of Atomic and Molecular Sciences, Academia Sinica, Taipei, Taiwan 106
}

Received 23 January 2003; accepted 25 April 2003

\begin{abstract}
A range of silanylene-spaced divinylbenzene copolymers (1) and the corresponding monomers (2) have been synthesized by the rhodium-catalyzed hydrosilylation of the corresponding bisalkynes with bissilyl hydrides, and the photophysical properties of $\mathbf{1}$ and $\mathbf{2}$ have been investigated. The silicon moiety in $\mathbf{1}$ serves as an insulating tetrahedral spacer that makes 1 highly folded. The two chromophores may be in close proximity such that a ground-state intrachain interaction between two conjugated moieties through space might occur. () 2003 Wiley Periodicals, Inc. J Polym Sci
\end{abstract} Part A: Polym Chem 41: 2218-2231, 2003

Keywords: silanylene; divinylbenzene; copolymers; photophysics; ground-state interaction; fluorescence; UV-vis spectroscopy

\section{INTRODUCTION}

There has been a burgeoning interest in the synthesis and photophysics of silanylenespaced conjugated copolymers. ${ }^{1-23}$ The tetrahedral silanylene linkers may serve as insulators such that the electron-hole excitation may be localized in the isolated conjugated segments in these polymers. Alternatively, energy transfer between the neighboring donor-acceptor chromophores separated by the silanylene moiety may also occur. ${ }^{22}$ In addition, the presence of

Correspondence to: T.-Y. Luh (E-mail: tyluh@chem. sinica.edu.tw)

Journal of Polymer Science: Part A: Polymer Chemistry, Vol. 41, 2218-2231 (2003) ๑) 2003 Wiley Periodicals, Inc. these tetrahedral silanylene groups could also lead the polymers to more flexible conformations so that the polymers may be highly folded. Consequently, the two $\pi$-conjugated moieties may be in close proximity so that intrachain $\pi-\pi$ interactions between chromophores may occur. ${ }^{24-33}$ In our preliminary communication, we found that silanylene-spaced $p$-divinylbenzene copolymer exhibited dual fluorescence spectra. $^{23}$ Significant intrachain interactions between lumophores in $\mathbf{1 a}$ both at the ground state and at the excited state could occur, and such interactions were more important as the polymer became larger. We report here a systematic structure-activity investigation of the photophysics of a range of silanylene-spaced divinylbenzene copolymers (1): 


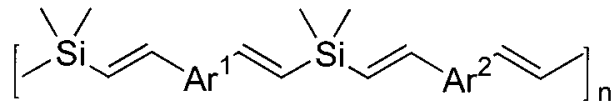

1a $\mathrm{Ar}^{1}=\mathrm{Ar}^{2}=1,4-\mathrm{C}_{6} \mathrm{H}_{4}$

1b $\mathrm{Ar}^{1}=A r^{2}=1,3-\mathrm{C}_{6} \mathrm{H}_{4}$

1c $\mathrm{Ar}^{1}=1,4-\mathrm{C}_{6} \mathrm{H}_{4}, \mathrm{Ar}^{2}=1,3-\mathrm{C}_{6} \mathrm{H}_{4}$

1d $\mathrm{Ar}^{1}=\mathrm{Ar}^{2}=2.5-\mathrm{F}_{2}-1,4-\mathrm{C}_{6} \mathrm{H}_{2}$

1e $\mathrm{Ar}^{1}=1,4-\mathrm{C}_{6} \mathrm{H}_{4}, \mathrm{Ar}^{2}=\mathrm{RO}_{\mathrm{RO}}^{\mathrm{OR}}$

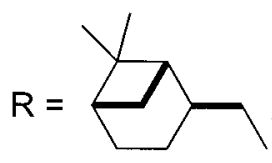<smiles>C[Si](C)(/C=C/[Al]/C=C/c1ccccc1)/C=C/[Al]/C=C/[Si](C)(C)/C=C/c1ccccc1</smiles>

$2 \mathrm{a} \mathrm{Ar}=1,4-\mathrm{C}_{6} \mathrm{H}_{4}$

$2 \mathbf{b ~ A r}=1,3-\mathrm{C}_{6} \mathrm{H}_{4}$

$2 \mathrm{c} A r=2.5-\mathrm{F}_{2}-1,4-\mathrm{C}_{6} \mathrm{H}_{2}$<smiles>[R20]c1cc(C)c([R])cc1C</smiles><smiles>CCC1CCC2CC1(C)C2</smiles>

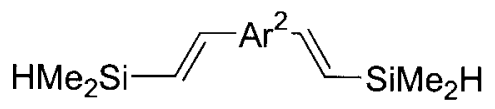

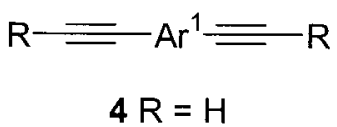

3 a $\mathrm{Ar}=1,4-\mathrm{C}_{6} \mathrm{H}_{4}$

b $\mathrm{Ar}=1,3-\mathrm{C}_{6} \mathrm{H}_{4}$

c $\mathrm{Ar}=2,5-\mathrm{F}_{2}-1,4-\mathrm{C}_{6} \mathrm{H}_{2}$
a $\mathrm{Ar}=1,4-\mathrm{C}_{6} \mathrm{H}_{4}$
b $\mathrm{Ar}=1,3-\mathrm{C}_{6} \mathrm{H}_{4}$
c $A r=2,5-\mathrm{F}_{2}-1,3-\mathrm{C}_{6} \mathrm{H}_{2}$

\section{RESULTS}

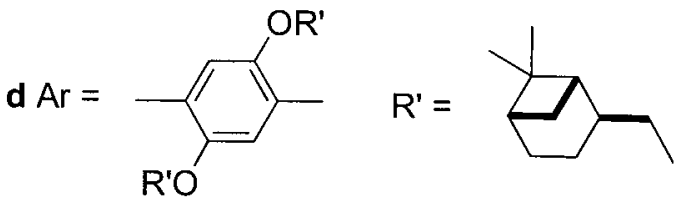

\section{Syntheses}

A series of silanylene-spaced divinylbenzene polymers (1) have been synthesized by the rhodium-catalyzed hydrosilylation ${ }^{34}$ of bisalkynes (4) with bissilylhydrides (3):

The number-average molecular weights $\left(M_{\mathrm{n}}\right.$ 's) of 1 depend on the reaction conditions. A higher concentration, a higher temperature, or a longer reaction time leads to the formation of 1 with a higher degree of polymerization. Representative examples are described in the Experimental sec-

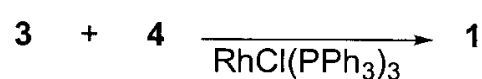


tion. The monomeric model compounds (2) have been prepared similarly:

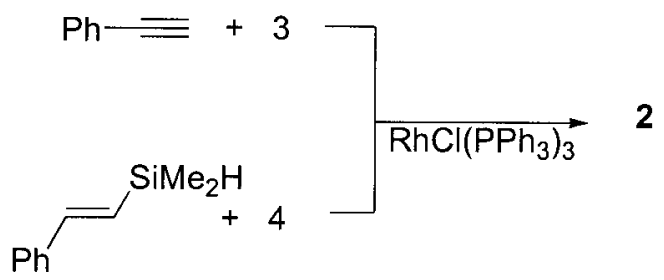

The synthetic strategy of $\mathbf{3}$ is mainly based on the silylolefination of the corresponding dithioacetals followed by the reduction of the corresponding $\mathrm{Si}-\mathrm{O}$ bond ${ }^{35-38}$ whereas the Sonogashira reaction $^{39}$ has been employed for the synthesis of 4 . The details are summarized in the Experimental section.

\section{Absorption Spectra}

The ultraviolet-visible (UV-vis) spectra of the copolymers (1) and their corresponding monomeric model compounds (2) are shown in Figure $1(\mathrm{a}-\mathrm{e})$, and the maximum wavelength $\left(\lambda_{\max }\right)$ for each of these molecules is summarized in Table 1. Some interesting features can be observed for the absorption of copolymers 1a-1d. As shown in Figure $1(\mathrm{a}-\mathrm{d})$, besides the absorption at the corresponding $\lambda_{\text {max }}$ 's, there is a tailing absorption extended to the longer wavelength for 1a-1d.

Polymer 1e has bulky alkoxy substituents. The UV-vis spectrum for 1e appears to be not very different from that of $\mathbf{2 d}$ [Fig. 1(e)], and there is no longer a wavelength tailing absorption for $\mathbf{1 e}$.

\section{Emission Spectra}

The emission spectra of copolymers 1a-1d are shown in Figure 2. With the exception of 1e, all the 1 polymers exhibit dual fluorescence spectra (Fig. 2). In addition to the higher energy emission, which is comparable to those for the corresponding monomers (2), there exists an emission in the longer wavelength region. The emission pattern in this longer wavelength region depends on the nature of the chromophore and on the degree of polymerization of $\mathbf{1}$. The profile for each of these spectra remains unchanged with the concentration $\left(10^{-2}\right.$ to $\left.10^{-4} \mathrm{~g} / \mathrm{L}\right)$. Some of these spectra exhibit distinct vibronic fine structures at the longer wavelength emission. The fluorescence lifetimes at different wavelengths and the quan- tum yields for both $\mathbf{2}$ and $\mathbf{1}$ are also summarized in Table 1.

The excitation spectra for each of the 1 polymers are compared with the absorption spectra of the same chromophore shown in Figure 1. The relative intensity at longer wavelengths in these excitation spectra appears to be much higher than that in the absorption profile for copolymers 1a-1e.

\section{DISCUSSION}

\section{Role of the Silanylene Moiety in 1}

On the basis of the spectroscopic properties of the 1 copolymers and the corresponding 2 monomers shown in Figures 1 and 2, it is apparent that the silicon moiety in $\mathbf{1}$ plays two interesting roles dictating the photophysical properties of $\mathbf{1}$. First, it can serve as an insulating spacer. As such, both the absorption and emission spectra for $\mathbf{1}$ and $\mathbf{2}$ having the same conjugated moiety will be alike. Copolymer 1e is a representative example. Second, the silicon moiety has a tetrahedral structure, and 1 can be expected to be highly folded. Accordingly, the two chromophores may be in close proximity such that intrachain interactions between two conjugated moieties through space might occur. The fluorescence spectra shown in Figure 2 are typical examples illustrating this phenomenon. The emission profile remains essentially unchanged when the concentration of polymer $1 \mathrm{~b}$ ranges from $10^{-2}$ to $10^{-4} \mathrm{~g} / \mathrm{L}$. This observation suggests that the interactions between chromophores, if any, should occur intramolecularly at these concentrations.

\section{Mononuclear Divinylbenzene-Silanylene Copolymers}

Three different kinds of divinylbenzene-silanylene copolymers $(\mathbf{1 a - 1 c})$ are compared. Polymer 1a has $p$-divinylbenzene chromophores, and polymer $\mathbf{1 b}$ contains $m$-divinylbenzene moieties, whereas polymer 1c consists of alternating $p$ - and $m$-divinylbenzene groups separated by the silicon atom. No significant shifts in the absorption spectra between polymers 1a-1c and the corresponding monomers $\mathbf{2 a}$ and $\mathbf{2 b}$ have been observed. However, there appears to be a tailing weak absorption in the region of $340-400 \mathrm{~nm}$ for $\mathbf{1 a - 1 c}$, and the intensity in this region slightly increases with the degree of polymerization. ${ }^{23}$ 
Polymer 1a exhibits dual fluorescence spectra (Fig. 2). The higher energy emissions around 340 and $360 \mathrm{~nm}$ for $1 \mathbf{a}$ are compatible with those for 2a. The relative intensity of the emission in the blue light region increases with the degree of polymerization of 1a, and vibronic fine structures have been observed in this region. The emission profiles remain essentially unchanged with the concentration (5-100-fold) and solvents ( $<8 \mathrm{~nm}$ in $\mathrm{MeCy}$, benzene, or $\mathrm{CHCl}_{3}$ ). Time-resolved fluorescence spectra of $\mathbf{1 a}\left(M_{\mathrm{n}}=10,700\right)$ and $\mathbf{2 a}$ in $\mathrm{CHCl}_{3}$ have been monitored at 341 and $414 \mathrm{~nm}$. The fluorescence of $1 \mathrm{a}$ at $414 \mathrm{~nm}$ shows a slow decay with a lifetime $(\tau)$ of $1.1 \mathrm{~ns}$. However, both 1a and $\mathbf{2 a}$ exhibit a fast fluorescent decay $(\tau=0.1$ $\mathrm{ns}$ ) at $341 \mathrm{~nm}$. When the fluorescence spectrum of $\mathbf{1 a}$ is monitored at a 1-ns delay time after laser excitation, only a low-energy emission can be observed (Fig. 3). These data suggest that the emission of $1 \mathbf{a}$ at these two wavelengths might arise from different species.

In the excitation spectrum for 1a [Fig. 1(a)], the intensity at $375 \mathrm{~nm}$ is substantially enhanced in comparison with that in the absorption spectrum. This observation indicates that significant intrachain interactions between chromophores ${ }^{40}$ in 1a both at the ground state and at the excited state might occur, and such interactions seem to be more important as the polymer becomes larger. In other words, the opportunity for one chromophore unit in 1a located proximal to the other in space would increase with the molecular weight. Intrachain aggregation of chromophores has also been observed in block copolymers obtained by the ring-opening metathesis polymerization of 2,2-paracyclophanene and norbornene. ${ }^{41-44}$

The photophysical behaviors of polymers $\mathbf{1 b}$ and 1c are similar to those of 1a. Again, dual fluorescence emissions have been observed for each of these polymers, vibronic fine structures being found at longer wavelengths (Fig. 2). The higher energy emissions around 340 and $360 \mathrm{~nm}$ for $\mathbf{1 b}$ and $\mathbf{1 c}$ are comparable to those for $\mathbf{2 a}$ and 2b. A peak at about $370 \mathrm{~nm}$ in the excitation spectra for 1b and 1c [Fig. 1(b,c)], in comparison with the respective absorption spectra, indicates that intrachain interactions between chromophores may also occur at both the ground state and the excited state. This result is similar to that observed for 1a, as previously described.

The $m$-divinylbenzene chromophore has a shorter conjugation length. Therefore, both the absorption maximum and emission wavelength for monomer $\mathbf{2 b}$ and polymer $\mathbf{1 b}$ appear expectedly at shorter wavelengths, as shown in Table 1 and Figures 1(b,c) and 2. The longer wavelength emission for $\mathbf{1 b}$ occurs at $393 \mathrm{~nm}$ with a fluorescence lifetime of $\tau=0.9 \mathrm{~ns}$. The fluorescence lifetime at $414 \mathrm{~nm}$ for $1 \mathrm{c}(\tau=1.1 \mathrm{~ns})$ is comparable to that for 1a at the same wavelength $(\tau=1.1$ $\mathrm{ns})$. However, there is an additional emission at $393 \mathrm{~nm}$ for 1c, and the lifetime of $0.8 \mathrm{~ns}$ is similar to that for the all-meta isomer $\mathbf{1 b}(\tau=0.9 \mathrm{~ns})$. The difference in the lifetimes for the emission at 414 and $393 \mathrm{~nm}$ for $1 \mathrm{c}$ indicates that they arise from different species. As mentioned earlier, the emission in this region is ascribed to the strong intrachain interaction between two chromophores at both the ground and excited states. The similarities in the lifetimes for $\mathbf{1 c}$ and for $\mathbf{1 a}$ and $\mathbf{1 b}$ at respective wavelengths suggest that the interaction pattern might be alike. Presumably, chromophores in $\mathbf{1 b}$ having comparable energy would interact preferentially.

\section{Substituted Divinylbenzene-Silyene Copolymers}

The introduction of a substituent into the aromatic ring of the divinylbenzene chromophores may cause changes in the electronic states of these moieties so that the photophysical properties may be modified. Therefore, the 2,5-difluoro1,4-divinylbenzene/silanylene copolymer (1d) and the corresponding monomer $(\mathbf{2 c})$ have been subjected to spectroscopic analysis. As shown in Figure 1(d), the absorption spectra for $\mathbf{1 d}$ and $\mathbf{2 c}$ are compared with the excitation spectrum for $\mathbf{1 d}$. Although the $\lambda_{\max }$ values for $\mathbf{1 d}$ and $\mathbf{2 c}$ are similar, the tailing in the longer wavelength regions appears to be characteristic. The relative intensity at this longer wavelength region in the absorption spectrum for 1d is less than that in the excitation spectrum for 1 d. These results again suggest that interactions of the fluoro-substituted chromophores in 1d may take place even at the ground state. The interactions of polyfluoro-substituted benzene moieties with other aromatic rings in the solid state are well documented. ${ }^{45}$ The fluorescence spectra shown in Figure 2 also exhibit longer wavelength emissions because of interactions of lumiphores similar to those of unsubstituted divinylbenzene chromophores described in the previous paragraphs. The presence of the fluorine substituent does not change the spectroscopic profiles in $\mathbf{1 d}$.

A fluorine atom is small, and the presence of a fluoro substituent does not alter the steric hin- 


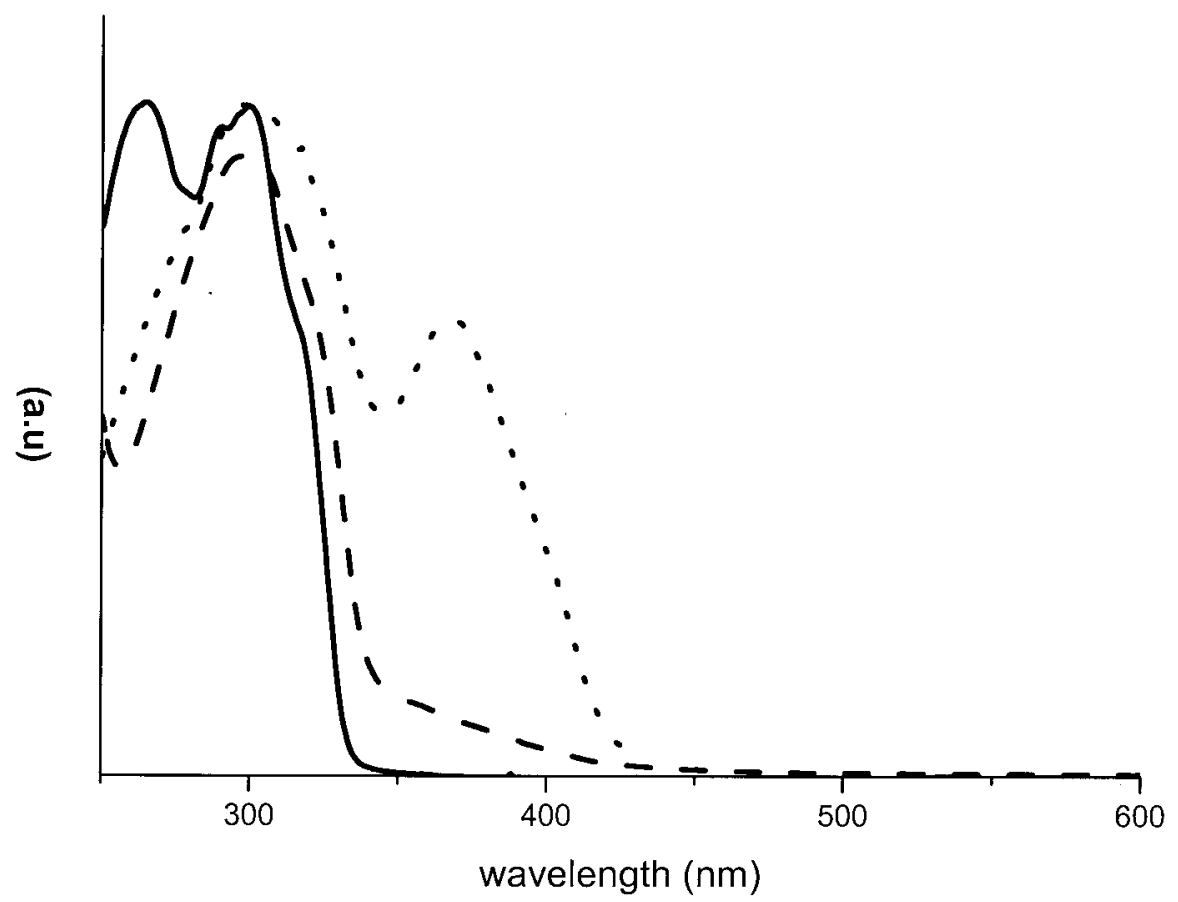

(a)

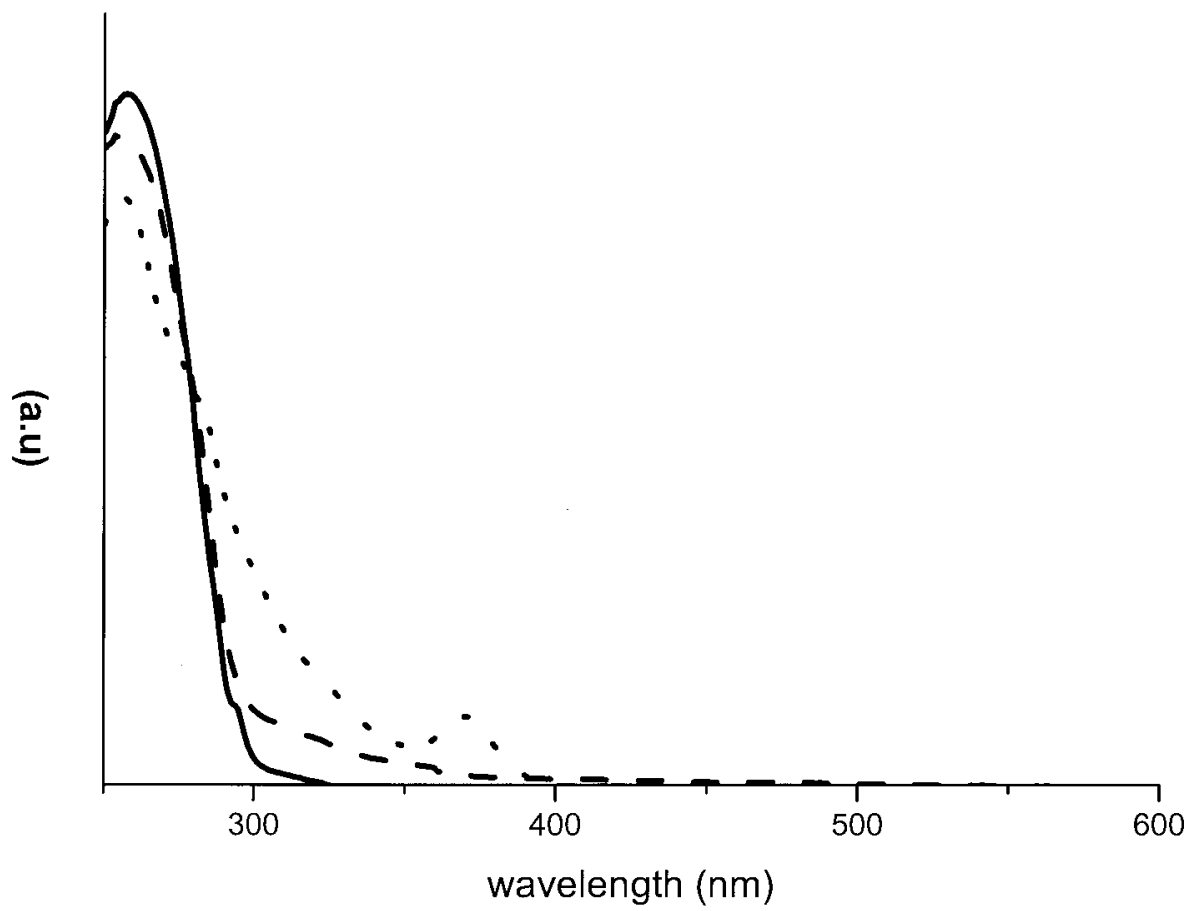

(b)

Figure 1. Absorption spectra for $\mathbf{1}$ (dashed line) and $\mathbf{2}$ (solid line) and an excitation spectrum for $\mathbf{1}$ (dotted line) in $\mathrm{CHCl}_{3}$ : (a) $\mathbf{1 a}\left(M_{\mathrm{n}}=10,700\right), \mathbf{2 a}$, and an excitation spectrum monitored at $414 \mathrm{~nm}$; (b) $\mathbf{1 b}\left(M_{\mathrm{n}}=3000\right), \mathbf{2 b}$, and an excitation spectrum monitored at $392 \mathrm{~nm}$; (c) $\mathbf{1 c}\left(M_{\mathrm{n}}=3500\right), \mathbf{2 b}$, and an excitation spectrum monitored at $415 \mathrm{~nm}$; (d) $1 \mathbf{d}\left(M_{\mathrm{n}}=4800\right), \mathbf{2 c}$, and an excitation spectrum monitored at $417 \mathrm{~nm}$; and (e) $1 \mathbf{e}\left(M_{\mathrm{n}}=15,900\right), \mathbf{2 d}$, and an excitation spectrum monitored at $418 \mathrm{~nm}$. 


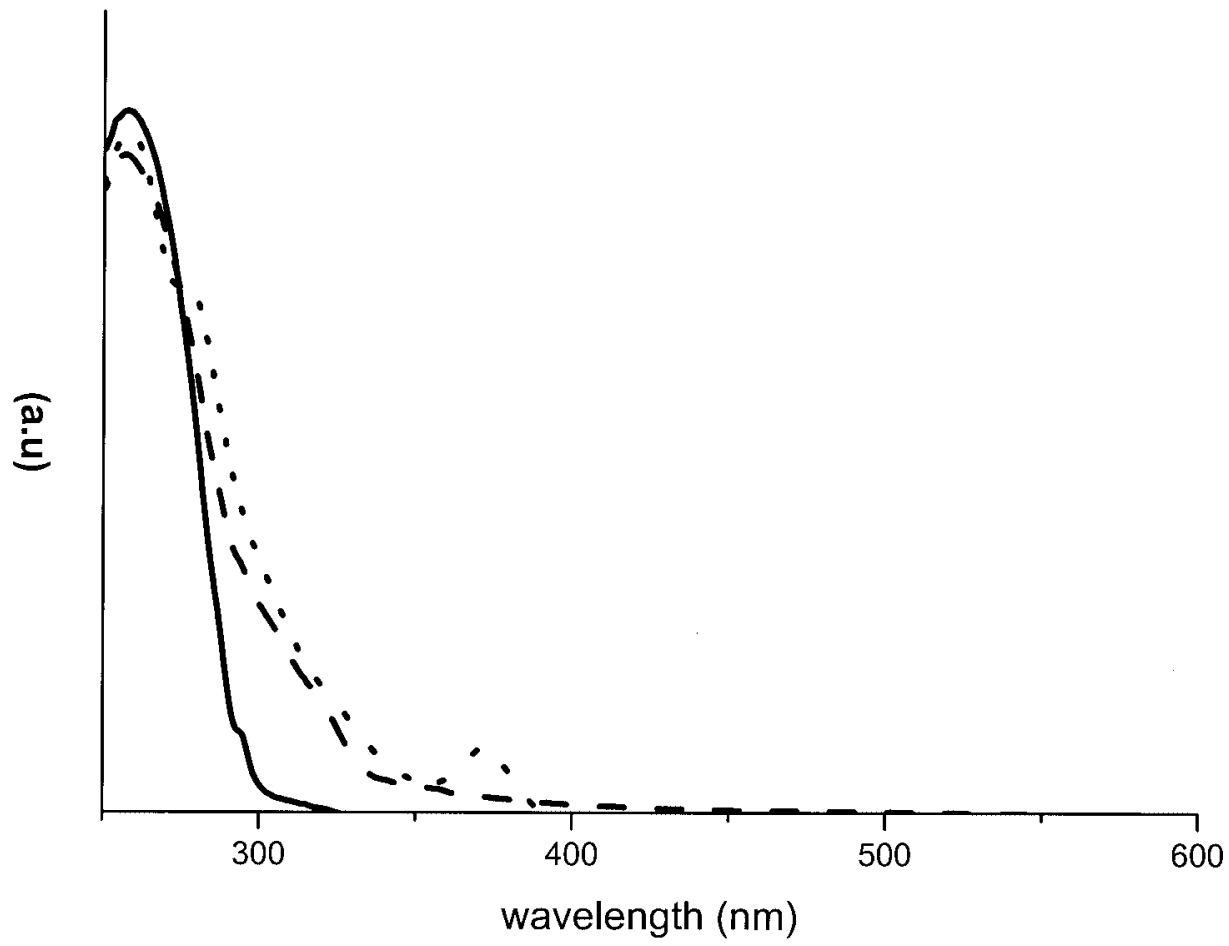

(c)

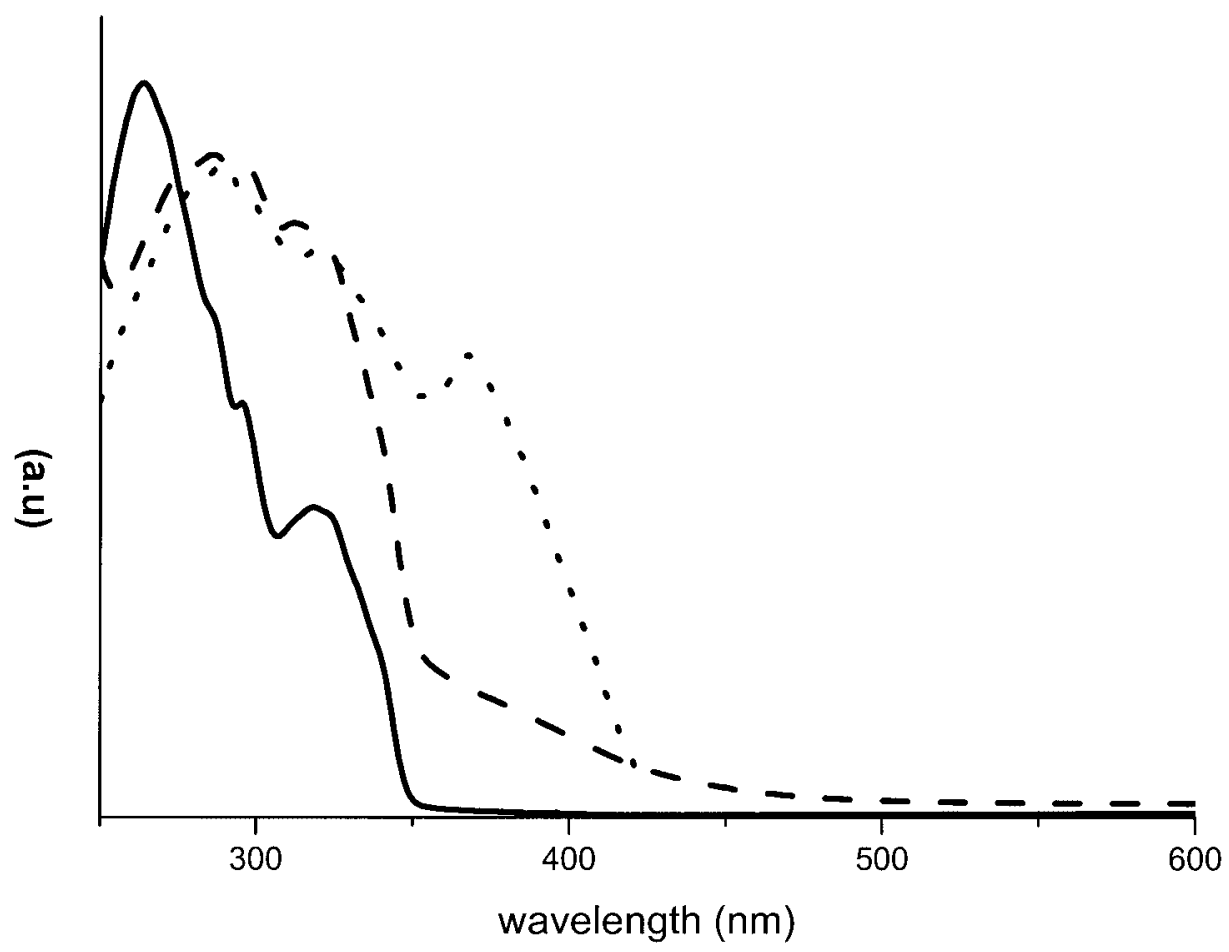

(d)

Figure 1. (Continued from the previous page) 


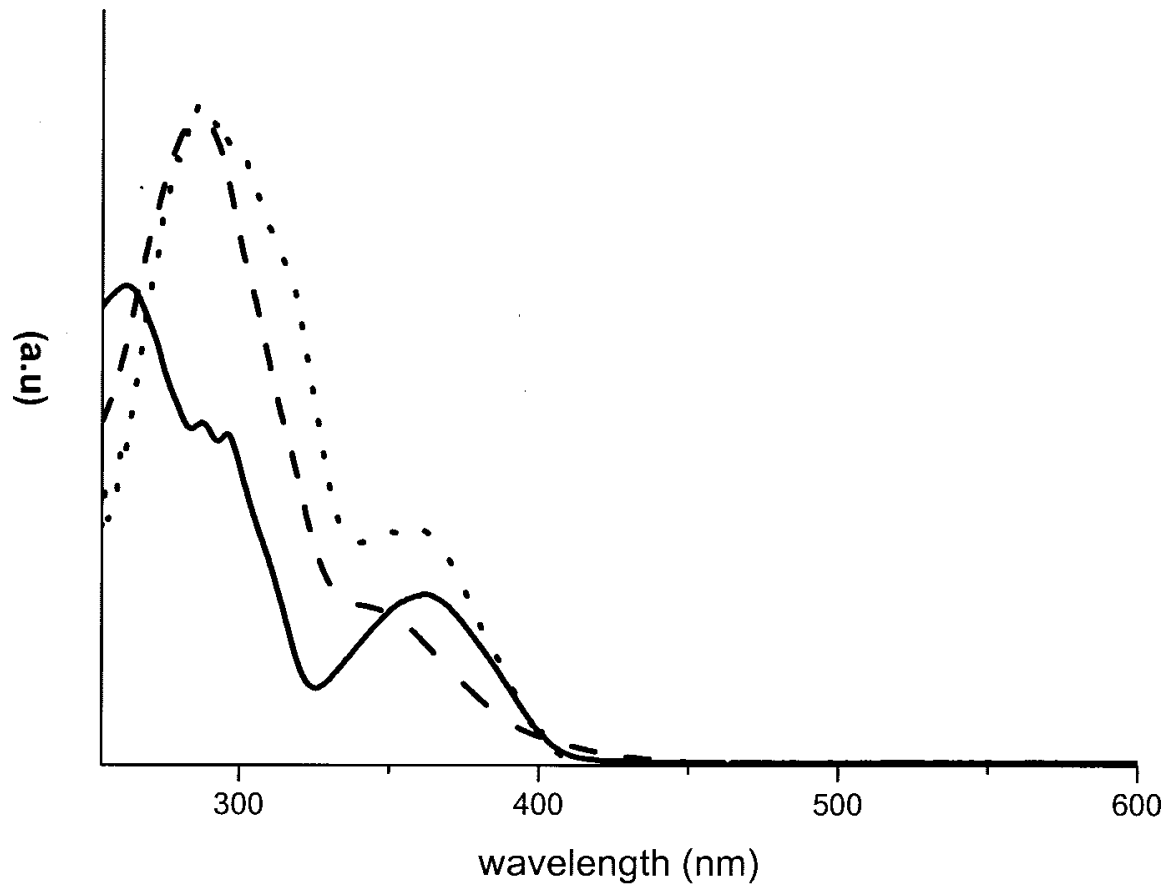

(e)

Figure 1. (Continued from the previous page)

Table 1. Photophysical Properties of Polymers 1a-1e and Monomers 2a-2d Measured in $\mathrm{CHCI}_{3}$

\begin{tabular}{|c|c|c|c|c|c|c|}
\hline & $M_{\mathrm{n}}(\mathrm{PDI})$ & $\lambda_{\max }(\mathrm{nm})$ & $\lambda_{\mathrm{em}}(\mathrm{nm})^{\mathrm{a}}$ & $\tau(\mathrm{ns})^{\mathbf{b}}$ & $\Phi_{\mathrm{f}}^{\mathrm{c}}$ & $\lambda_{\text {excitation }}(\mathrm{nm})$ \\
\hline \multirow[t]{4}{*}{$1 \mathbf{a}$} & $10,700(3.5)$ & 300 & 341 & 0.1 & 0.03 & 300 \\
\hline & & $360^{\mathrm{d}}$ & 354 & & & 367 \\
\hline & & & 414 & 1.1 & & \\
\hline & & & 441 & & & \\
\hline \multirow[t]{2}{*}{$\mathbf{1 b}$} & $3,000(2.7)$ & $258^{\mathrm{d}}$ & 354 & & 0.15 & 258 \\
\hline & & & 392 & 0.9 & & 370 \\
\hline \multirow[t]{4}{*}{ 1c } & $3,500(3.6)$ & $260^{\mathrm{d}}$ & 356 & 0.1 & 0.14 & 258 \\
\hline & & & 393 & 0.8 & & \\
\hline & & & 415 & 1.1 & & 372 \\
\hline & & & 441 & & & 372 \\
\hline \multirow[t]{3}{*}{$1 d$} & $4,800(2.7)$ & 286 & 350 & 0.3 & 0.08 & 287 \\
\hline & & $313^{\mathrm{e}}$ & 417 & 1.2 & & \\
\hline & & & 441 & 1.4 & & 368 \\
\hline $1 \mathbf{e}$ & $15,900(2.2)$ & 286 & 418 & 2.6 & 0.32 & 286 \\
\hline \multirow[t]{2}{*}{$\mathbf{2 a}$} & & 264 & 335 & 0.1 & 0.05 & \\
\hline & & 300 & 354 & & & \\
\hline $\mathbf{2 b}$ & & 260 & 354 & 0.3 & 0.15 & \\
\hline \multirow[t]{2}{*}{$2 \mathrm{c}$} & & 258 & 348 & 0.3 & 0.09 & \\
\hline & & 295 & 360 & & & \\
\hline \multirow[t]{2}{*}{$2 d$} & & 262 & 418 & 2.5 & 0.36 & \\
\hline & & 360 & & & & \\
\hline
\end{tabular}

a The absorption $\lambda_{\max }$ was used to excite the substrate.

${ }^{\mathrm{b}} \tau$ was obtained from the time-resolved spectra with $y=y_{0}+A_{1} \exp \left(x_{0}-x\right) t+A_{2} \exp \left(x_{0}-x\right) t$ for simulation.

c Quantum yield.

d Tailing extended to about $400 \mathrm{~nm}$.

e Tailing extended to about $460 \mathrm{~nm}$. 


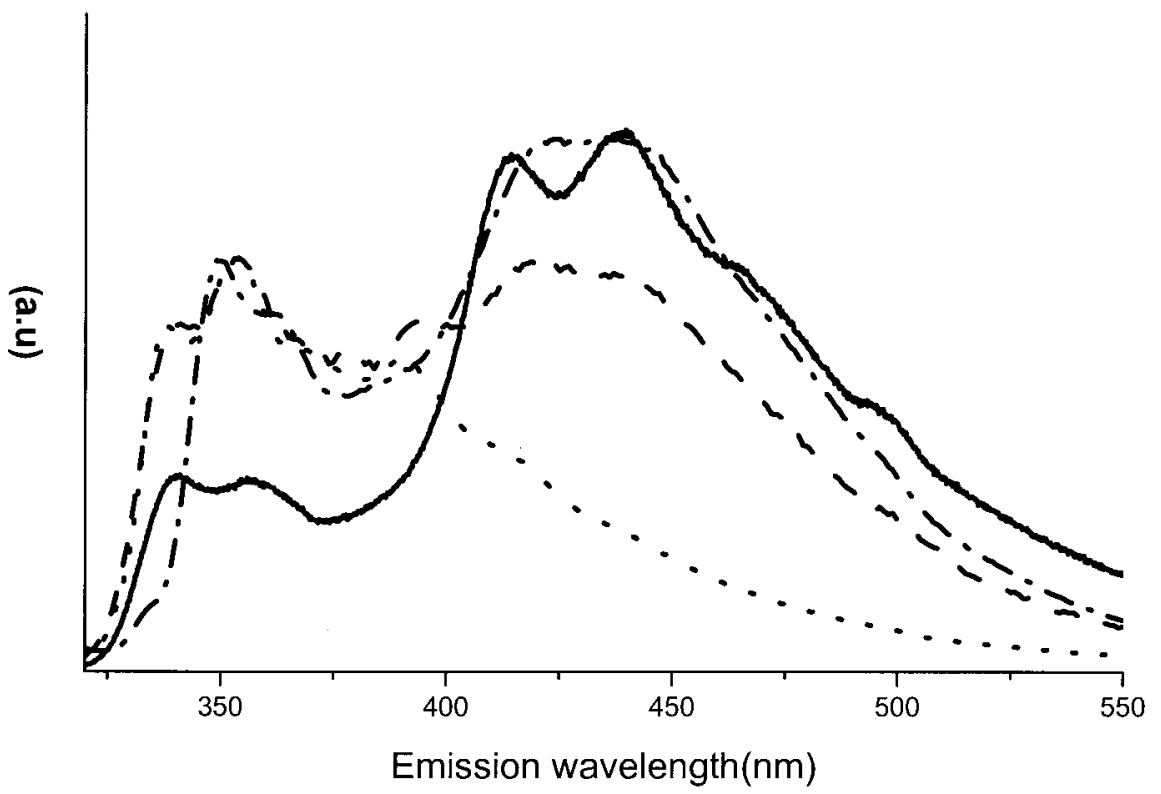

Figure 2. Emission spectra for 1a $\left(M_{\mathrm{n}}=10,700\right.$; solid line), $1 \mathbf{b}\left(M_{\mathrm{n}}=3000\right.$; dotted line), 1c $\left(M_{\mathrm{n}}=6200\right.$; dashed line $)$, and $\mathbf{1 d}\left(M_{\mathrm{n}}=4800\right.$; dashed-dotted $)$ in $\mathrm{CHCl}_{3}$.

drance significantly. Despite the electron-withdrawing character for the fluorine substituent, polymer 1d is expected to fold in a manner similar to that of simple divinylbenzene copolymer $\mathbf{1 a}$.
The introduction of a bulky substituent may, however, alter the situation. Therefore, the emission profiles for polymer 1e appear similar to that for the corresponding monomer $\mathbf{2 d}$, no excimer-like

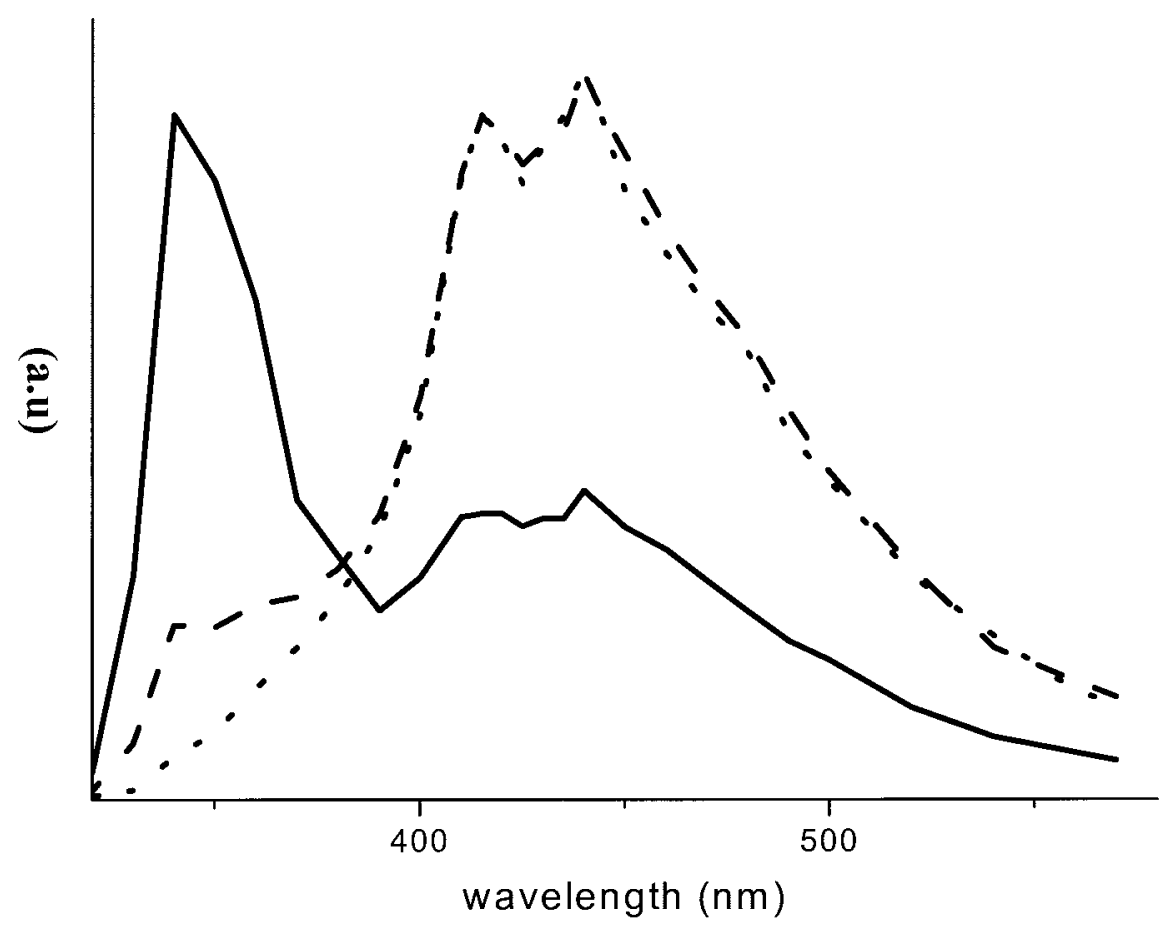

Figure 3. Time-resolved spectra of $\mathbf{1 a}\left(M_{\mathrm{n}}=10,700\right)$ in $\mathrm{CHCl}_{3}$ monitored at different decay times: 0 (solid line), 0.3 (dashed line), and $1 \mathrm{~ns}$ (dotted line). 
emission being observed in the fluorescence spectrum. In addition, no tailing in the longer wavelength has been observed in the UV-vis spectrum for 1e [Fig. 1(e)]. Apparently, the bulky alkoxy substituent prohibits the interactions between chromophores.

\section{CONCLUSIONS}

We have demonstrated the mode of intrachain interaction between chromophores in silanylenespaced divinylbenzene copolymers (1). When the benzene moiety contains no bulky substituents, interchromophoric contact prevails, leading to ground-state interactions. When the chromophores are substituted with bulky substituents, the intrachain interactions appear to be negligible for steric reasons. These results may provide useful insights into how chromophores in conjugated polymers (particularly those with structural defects) interact intramolecularly.

\section{EXPERIMENTAL}

${ }^{1} \mathrm{H}$ NMR spectra were recorded in a $\mathrm{CDCl}_{3}$ solution on Bruker AC-200, AC-300, and AC-400 spectrometers. Mass spectrometry (MS) and high-resolution mass spectrometry (HRMS) were measured on a Finnigan-TSQ-46C spectrometer and a JEOL SX-102A spectrometer, respectively. UVvis absorption spectra were determined with a Shimadzu UV 1601-PC spectrometer. The fluorescence emission was detected with an AmincoBowman series 2 luminescence spectrometer with a slit width of $2.5 \mathrm{~nm}$ (SLM-Aminco, Urbana, IL). The synthesis of polymer $\mathbf{1 a}$ and its relative monomer $2 \mathbf{a}$ has been published elsewhere. ${ }^{5,6}$

\section{1,3-Bis(2-dithiolanyl)benzene (6a)}

A $\mathrm{CHCl}_{3}$ solution $(100 \mathrm{~mL})$ of $\mathbf{5 a}(8.04 \mathrm{~g}, 60.0$ $\mathrm{mmol}), \mathrm{BF}_{3} \cdot \mathrm{Et}_{2} \mathrm{O}(1.5 \mathrm{~mL}, 6.0 \mathrm{mmol})$, and $1,2-$ ethanedithiol (14.8 mL, $160 \mathrm{mmol}$ ) was stirred at room temperature for $4 \mathrm{~h}$. The mixture was poured into $10 \% \mathrm{NaOH}$, and the organic layer was washed with $10 \% \mathrm{NaOH}(50 \mathrm{~mL} \times 3)$ and brine $(50 \mathrm{~mL})$ and dried $\left(\mathrm{MgSO}_{4}\right)$. The solvent was removed in vacuo to give $\mathbf{6 a}(14.7 \mathrm{~g}, 86 \%)$.

mp: $102-103{ }^{\circ} \mathrm{C}$ (hexane). ${ }^{1} \mathrm{H}$ NMR $(300 \mathrm{MHz}$, $\left.\mathrm{CDCl}_{3}, \delta\right): 3.20-3.60(\mathrm{~m}, 8 \mathrm{H}), 5.60(\mathrm{~s}, 2 \mathrm{H}), 7.25(\mathrm{t}$, $J=6.9 \mathrm{~Hz}, 1 \mathrm{H}), 7.42(\mathrm{~d}, J=6.9 \mathrm{~Hz}, 2 \mathrm{H}), 7.61(\mathrm{~s}$, $1 \mathrm{H}) .{ }^{13} \mathrm{C} \mathrm{NMR}\left(75 \mathrm{MHz}, \mathrm{CDCl}_{3}, \delta\right): 40.2,56.0$,
127.5, 127.7, 128.7, 140.6. HRMS Calcd. for $\mathrm{C}_{12} \mathrm{H}_{14} \mathrm{~S}_{4}: 285.9978$. Found: 285.9983. Elem. ANAL. Calcd.: C, 50.31\%; H, 4.93\%. Found: C, 50.07\%; H, $4.82 \%$.

\section{1,3-Bis(2-dimethylsilanyl)vinylbenzene (3b)}

The solvent of a tetrahydrofuran (THF) solution of $\mathrm{Me}_{2}\left({ }^{\mathrm{i}} \mathrm{PrO}\right) \mathrm{SiCH}_{2} \mathrm{MgCl}$ (100 mmol), prepared from $\mathrm{Me}_{2}\left({ }^{\mathrm{i}} \mathrm{PrO}\right) \mathrm{SiCH}_{2} \mathrm{Cl}(18.6 \mathrm{~mL}, 100 \mathrm{mmol})$ and $\mathrm{Mg}$ turning (2.43 g, $100 \mathrm{mmol}$ ), was removed under reduced pressure, and the residue was evacuated. Under $\mathrm{N}_{2}$, a solution of $6 \mathbf{a}(2.86 \mathrm{~g}, 10$ $\mathrm{mmol})$ and $\mathrm{NiCl}_{2}\left(\mathrm{PPh}_{3}\right)_{2}(0.33 \mathrm{~g}, 0.5 \mathrm{mmol})$ in benzene $(100 \mathrm{~mL})$ was introduced, and the mixture was refluxed for $16 \mathrm{~h}$ and then poured into $5 \% \mathrm{Na}_{2} \mathrm{CO}_{3}$. The organic layer was separated, and the aqueous layer was extracted with ether (2 $\times 50 \mathrm{~mL}$ ). The combined organic portions were washed with $10 \% \mathrm{NaOH}(2 \times 50 \mathrm{~mL})$ and brine $(50 \mathrm{~mL})$ and dried $\left(\mathrm{MgSO}_{4}\right)$. The solvent was removed in vacuo to afford a gummy mass, which was taken in benzene (100 mL). $\mathrm{LiAlH}_{4}(1.6 \mathrm{~g}, 40$ $\mathrm{mmol}$ ) was then added, and the mixture was refluxed for $18 \mathrm{~h}$, cooled to room temperature, and quenched carefully with water. After filtration, the organic layer was dried $\left(\mathrm{MgSO}_{4}\right)$, and the solvent was removed in vacuo to give the residue, which was chromatographed on silica gel (hexane) to afford $\mathbf{3 b}$ (1.36 g, 55\%, two steps).

bp: $125{ }^{\circ} \mathrm{C}(0.2 \mathrm{mmHg}) .{ }^{1} \mathrm{H}$ NMR $(300 \mathrm{MHz}$, $\left.\mathrm{CDCl}_{3}, \delta\right): 0.22(\mathrm{~d}, J=3.6 \mathrm{~Hz}, 12 \mathrm{H}), 4.10-4.25(\mathrm{~m}$, $2 \mathrm{H}), 6.47(\mathrm{dd}, J=19.1 \mathrm{~Hz}, J=2.3 \mathrm{~Hz}, 2 \mathrm{H}), 6.95(\mathrm{~d}$, $J=19.1 \mathrm{~Hz}, 2 \mathrm{H}), 7.24-7.36(\mathrm{~m}, 3 \mathrm{H}), 7.50(\mathrm{~s}, 1 \mathrm{H})$. ${ }^{13} \mathrm{C}$ NMR (75 MHz, $\left.\mathrm{CDCl}_{3}, \delta\right):-4.0,124.5,126.2$, 126.4, 128.7, 138.4, 145.1. IR ( $\nu, \mathrm{KBr}): 2119 \mathrm{~cm}^{-1}$. HRMS Calcd. for $\mathrm{C}_{14} \mathrm{H}_{22} \mathrm{Si}_{2}: 246.1260$. Found: 246.1253. Elem. Anal. Calcd. for $\mathrm{C}_{14} \mathrm{H}_{22} \mathrm{Si}_{2}$ : C, $68.22 \%$; H, 9.00\%. Found: C, 67.73\%; H, 8.66\%.

\section{1,4-Diethynyl-2,5-difluorobenzene (4c)}

A solution of 7c $(X=\mathrm{Br}, 544 \mathrm{mg}, 2.0 \mathrm{mmol})$ in triethylamine $\left(\mathrm{Et}_{3} \mathrm{~N}\right)(20 \mathrm{~mL})$ was mixed with trimethylsilylacetylene $(588 \mathrm{mg}, 6.0 \mathrm{mmol}), \mathrm{CuI}$ (8 mg, $0.04 \mathrm{mmol}$ ), and $\mathrm{PdCl}_{2}\left(\mathrm{PPh}_{3}\right)_{2}(56 \mathrm{mg}, 0.08$ mmol). The mixture was refluxed under $\mathrm{N}_{2}$ for $12 \mathrm{~h}$. $\mathrm{Et}_{3} \mathrm{~N}$ was removed under reduced pressure, and the residue was taken in $\mathrm{Et}_{2} \mathrm{O}$ and filtered. The filtrate was washed with water, dried $\left(\mathrm{MgSO}_{4}\right)$, and evaporated in vacuo to give 8c (495 $\mathrm{mg}, 81 \%)$.

mp: 81-82 ${ }^{\circ} \mathrm{C}$ [methanol $(\mathrm{MeOH})$ ]. ${ }^{1} \mathrm{H}$ NMR $\left(300 \mathrm{MHz}, \mathrm{CDCl}_{3}, \delta\right): 0.24(\mathrm{~s}, 18 \mathrm{H}), 7.06-7.11(\mathrm{t}$, 
$J=7.2 \mathrm{~Hz}, 2 \mathrm{H}) .{ }^{13} \mathrm{C} \mathrm{NMR}\left(75 \mathrm{MHz}, \mathrm{CDCl}_{3}, \delta\right)$ : $-0.3,96.3,103.3,113.0$ (dd, $J=16,28 \mathrm{~Hz}), 119.8$ (m), $158.3(\mathrm{dd}, J=4.4,250 \mathrm{~Hz})$. IR $(\nu, \mathrm{KBr}): 2961$, $2902,2162,1493,1411,1260,872,838 \mathrm{~cm}^{-1} . \mathrm{m} / \mathrm{z}$ : 306. Elem. Anal. Calcd. for $\mathrm{C}_{16} \mathrm{H}_{20} \mathrm{~F}_{2} \mathrm{Si}_{2}: \mathrm{C}$, $62.70 \%$; H, 6.57\%. Found: C, 62.31; H 6.66\%.

To a suspension of $8 \mathbf{c}(612 \mathrm{mg}, 2.0 \mathrm{mmol})$ in $\mathrm{MeOH}(10 \mathrm{~mL})$ was added $\mathrm{K}_{2} \mathrm{CO}_{3}(56 \mathrm{mg}, 0.4$ $\mathrm{mmol}$ ), and the mixture was stirred at room temperature for $2 \mathrm{~h}$. The solvent was removed in vacuo, and the residue was chromatographed on silica gel [ethyl acetate $($ EtOAc)/hexane $=5: 95$ ] to afford $4 \mathbf{c}(279 \mathrm{mg}, 86 \%)$ as a solid.

$\mathrm{mp}: 132-134{ }^{\circ} \mathrm{C}\left(\mathrm{CH}_{2} \mathrm{Cl}_{2} /\right.$ hexane). ${ }^{1} \mathrm{H}$ NMR $\left(200 \mathrm{MHz} \mathrm{CDCl}_{3}, \delta\right): 3.39(\mathrm{~s}, 2 \mathrm{H}), 7.11-7.23(\mathrm{t}, J$ $=7.4 \mathrm{~Hz}, 2 \mathrm{H}) .{ }^{13} \mathrm{C} \mathrm{NMR}\left(75 \mathrm{MHz}, \mathrm{CDCl}_{3}, \delta\right): 75.5$, 85.0, $112.2(\mathrm{dd}, J=16,27 \mathrm{~Hz}), 120.0(\mathrm{~m}), 158.7$ $(\mathrm{dd}, J=4.4,250 \mathrm{~Hz})$. IR $(\nu, \mathrm{KBr}): 3289,3070$, 2119, 1753, 1501, 1410, 1206, 884, $717 \mathrm{~cm}^{-1} . \mathrm{m} / z$ : 162. Elem. Anal. Calcd. for $\mathrm{C}_{10} \mathrm{H}_{4} \mathrm{~F}_{2}$ : C, $74.07 \%$; H, 2.47\%. Found: C, 73.68\%; H, 2.83\%.

\section{1,4-Dicyano-2,5-difluorobenzene (9)}

To a solution of 7c $(X=\mathrm{Br}, 272 \mathrm{mg}, 1 \mathrm{mmol})$ in dry dimethylacetamide (4 mL) was added $\mathrm{CuCN}$ $(270 \mathrm{mg}, 3.0 \mathrm{mmol})$, and the mixture was heated at $160{ }^{\circ} \mathrm{C}$ for $4.5 \mathrm{~h}$. The solvent was removed in vacuo, and the residue was taken up in $\mathrm{CHCl}_{3}$. The organic extract was filtered over celite, and the residue was washed several times with $\mathrm{CHCl}_{3}$. The filtrate was evaporated in vacuo to give the residue, which was chromatographed on silica gel (EtOAc/hexane $=2: 98)$ to afford 9 (88 $\mathrm{mg}, 54 \%)$.

mp: $175-177{ }^{\circ} \mathrm{C}$ (Et ${ }_{2} \mathrm{O} /$ hexane $),{ }^{1} \mathrm{H}$ NMR $(200$ $\left.\mathrm{MHz} \mathrm{CDCl}_{3}, \delta\right): 7.52(\mathrm{t}, J=7.2 \mathrm{~Hz}, 2 \mathrm{H}) .{ }^{13} \mathrm{C} \mathrm{NMR}$ $\left(50 \mathrm{MHz}, \mathrm{CDCl}_{3}, \delta\right): 107.5(\mathrm{~d}, J=2.8 \mathrm{~Hz}), 111.1(\mathrm{~s})$, $121.2(\mathrm{~m}), 158.3(\mathrm{dd}, J=4.4,250 \mathrm{~Hz})$. IR $(\nu, \mathrm{KBr})$ : $2100 \mathrm{~cm}^{-1} . \mathrm{m} / \mathrm{z}: 164(\mathrm{M}+, 100 \%), 137,120.1,105$, 91, 77. Elem. Anal. Calcd. for $\mathrm{C}_{8} \mathrm{H}_{2} \mathrm{~F}_{2} \mathrm{~N}_{2}$ : C, 58.54\%; H, $1.22 \%$. Found: C, 58.11; H $1.10 \%$.

\section{2,5-Difluroterepthaldehyde (5b)}

To a solution of 9 (332 $\mathrm{mg}, 2.0 \mathrm{mmol}$ ) in benzene $(20 \mathrm{~mL})$ was slowly added diisobutylaluminum hydride (DIBAH) (1 M in hexane, $4.5 \mathrm{~mL})$ at the ambient temperature, and the mixture was stirred for a further period of $6 \mathrm{~h}$. To this mixture was added a mixture of $\mathrm{MeOH}$ and benzene (1:1, $2 \mathrm{~mL}$ ) followed by $\mathrm{MeOH}$ and water $(1: 1,2 \mathrm{~mL})$ and then $20 \% \mathrm{H}_{2} \mathrm{SO}_{4}(3 \mathrm{~mL})$, and the mixture was stirred for a further period of $20 \mathrm{~min}$. After being cooled to $0{ }^{\circ} \mathrm{C}$, the mixture was neutralized by the careful addition of a saturated $\mathrm{NaHCO}_{3}$ solution and extracted with EtOAc, and the organic layer was thoroughly washed with water and brine and dried $\left(\mathrm{MgSO}_{4}\right)$. The removal of the solvent in vacuo afforded a gummy material, which was chromatographed on silica gel (EtOAc/hexane $=5: 95)$ to afford $\mathbf{5 b}$ as a colorless solid ( $302 \mathrm{mg}$, $89 \%)$.

mp: $155-157{ }^{\circ} \mathrm{C} .{ }^{1} \mathrm{H} \mathrm{NMR}\left(200 \mathrm{MHz}, \mathrm{CDCl}_{3}, \delta\right)$ : $7.67(\mathrm{t}, J=7.2 \mathrm{~Hz}, 2 \mathrm{H}), 10.35(\mathrm{~s}, 2 \mathrm{H}) .{ }^{13} \mathrm{C} \mathrm{NMR}(75$ $\left.\mathrm{MHz} \mathrm{CDCl}_{3}, \delta\right): 116.2(\mathrm{~m}), 128.9(\mathrm{dd}, J=8,17 \mathrm{~Hz})$, 160.1 (dd, $J=4.4,256 \mathrm{~Hz}), 185.1$. IR ( $\nu, \mathrm{KBr}$ ): 1692 $\mathrm{cm}^{-1}$. Elem. Anal. Calcd. for $\mathrm{C}_{8} \mathrm{H}_{4} \mathrm{~F}_{2} \mathrm{O}_{2}$ : C, 56.48\%; $\mathrm{H}, 2.37 \%$. Found: C, $56.49 \%$; H, $2.59 \%$.

\section{2,5-Difluoro-1,4-bis(2-dithiolanyl)benzene (6b)}

To a solution of $\mathbf{5 b}$ (375 mg, $2.2 \mathrm{mmol})$ in $\mathrm{CHCl}_{3}$ $(25 \mathrm{~mL})$ were added 1,2-ethanedithiol $(620 \mathrm{mg}$, $6.6 \mathrm{mmol}$ ) and a catalytic amount of $\mathrm{BF}_{3} \cdot \mathrm{Et}_{2} \mathrm{O}$. The mixture was stirred at room temperature overnight, quenched with a $10 \%$ aqueous $\mathrm{NaOH}$ solution, and extracted with $\mathrm{CHCl}_{3}$. The organic extract was thoroughly washed with brine and dried $\left(\mathrm{MgSO}_{4}\right)$. The removal of the solvent in vacuo, followed by column chromatography on silica gel $(\mathrm{EtOAc} /$ hexane $=5: 95)$, afforded $\mathbf{6 b}$ (584 $\mathrm{mg}, 82 \%)$ as a solid.

mp: $135-137{ }^{\circ} \mathrm{C}$ (hexane). ${ }^{1} \mathrm{H}$ NMR $(200 \mathrm{MHz}$, $\left.\mathrm{CDCl}_{3}, \delta\right): 3.25-3.45(\mathrm{~m}, 8 \mathrm{H}), 5.79(\mathrm{~s}, 2 \mathrm{H}), 7.36(\mathrm{t}$, $J=8.4 \mathrm{~Hz}, 2 \mathrm{H}) .{ }^{13} \mathrm{C}$ NMR $\left(75 \mathrm{MHz}, \mathrm{CDCl}_{3}, \delta\right)$ : 39.7 (s), 47.3 (s), 115.7 (dd, $J=17,29 \mathrm{~Hz}$ ), 130.0 (dd, $J=10,23 \mathrm{~Hz}$ ), 154.1 (dd, $J=4,243 \mathrm{~Hz}$ ). $\mathrm{m} / z$ : 294. Elem. Anal. Calcd. for $\mathrm{C}_{22} \mathrm{H}_{12} \mathrm{~F}_{2} \mathrm{~S}_{4}$ : C, $44.69 \%$; H, 3.75\%. Found: C, $44.79 \%$; H, 3.56\%.

\section{2,5-Difluoro-1,4-bis(2-dimethylsilanyl)vinylbenzene} (3c)

To a solution of $\mathrm{Me}_{2}\left({ }^{\mathrm{i}} \mathrm{PrO}\right) \mathrm{SiCH}_{2} \mathrm{MgCl}$ prepared from $\left.\mathrm{Me}_{2}{ }^{(} \mathrm{PrO}\right) \mathrm{SiCH}_{2} \mathrm{Cl}(2.7 \mathrm{~g}, 16.3 \mathrm{mmol})$ and $\mathrm{Mg}$ (360 mg, $15 \mathrm{mmol}$ ) was added bisdithioacetal 6b $(480 \mathrm{mg}, 1.50 \mathrm{mmol})$ in toluene $(30 \mathrm{~mL})$ and $\mathrm{NiCl}_{2}\left(\mathrm{PPh}_{3}\right)_{2}$ (400 mg, $\left.0.6 \mathrm{mmol}\right)$. The mixture was refluxed for $32 \mathrm{~h}$ and then quenched with a saturated aqueous $\mathrm{NH}_{4} \mathrm{Cl}$ solution. The organic layer was extracted with $\mathrm{Et}_{2} \mathrm{O}$ and washed with a $10 \%$ aqueous $\mathrm{NaOH}$ solution and brine. The solvent was removed in vacuo to afford a gummy mass, which was taken in benzene. $\mathrm{LiAlH}_{4}(480$ $\mathrm{mg}, 14.1 \mathrm{mmol}$ ) was added, and the mixture was refluxed for $12 \mathrm{~h}$. After being cooled to room temperature, the mixture was slowly added to cold $\mathrm{Et}_{2} \mathrm{O}$, and $\mathrm{LiAlH}_{4}$ was quenched with the careful addition of water followed by a $10 \% \mathrm{NaOH}$ solu- 
tion. The organic layer was filtered through celite and dried $\left(\mathrm{MgSO}_{4}\right)$, and the solvent was removed in vacuo to afford a viscous liquid, which was chromatographed on silica gel (hexane) to afford 3c as an oil (95 mg, 23\%, two steps).

${ }^{1} \mathrm{H}$ NMR (200 MHz, $\left.\mathrm{CDCl}_{3}, \delta\right): 0.21(\mathrm{~d}, J=2.3$ $\mathrm{Hz}, 2 \mathrm{H}), 4.19(\mathrm{~m}, 1 \mathrm{H}), 6.49$ (dd, $J=2.6,19.2 \mathrm{~Hz})$, $7.06(\mathrm{~d}, J=19.2 \mathrm{~Hz}, 2 \mathrm{H}), 7.17(\mathrm{t}, J=8.6 \mathrm{~Hz}, 2 \mathrm{H})$. ${ }^{13} \mathrm{C}$ NMR (75 $\left.\mathrm{MHz}, \mathrm{CDCl}_{3}, \delta\right):-4.1,112.9$, 126.7, 130.6, 135.7, 155 (dd, $J=2.7,241 \mathrm{~Hz}$ ). HRMS Calcd. for $\mathrm{C}_{14} \mathrm{H}_{20} \mathrm{~F}_{2} \mathrm{Si}_{2}$ : 282.1071. Found: 282.1077.

\section{1,4-Diiodo-2,5-dimyrtoxybenzene (7d)}

To a solution of $\mathbf{1 0}(9.20 \mathrm{~g}, 25.4 \mathrm{mmol})$ and $\mathbf{1 1}^{22}$ (16.5 g, $53.5 \mathrm{mmol})$ in DMSO (175 mL) was added $\mathrm{KOH}(4.5 \mathrm{~g}, 80.2 \mathrm{mmol})$. After being stirred at room temperature for $36 \mathrm{~h}$, the mixture was poured into water and extracted twice with ether. The combined organic layers were washed with a $10 \% \mathrm{NaOH}$ solution, water, and brine successively, dried $\left(\mathrm{MgSO}_{4}\right)$, and then filtered. The solvent was removed in vacuo to give $\mathbf{7 d}(0.5 \mathrm{~g}, 59 \%)$. mp: $109-110{ }^{\circ} \mathrm{C}\left(\mathrm{CHCl}_{3} / \mathrm{CH}_{3} \mathrm{OH}\right) . \alpha_{\mathrm{D}}^{25}:-4.0$ (c 0.1 $\left.\mathrm{g} / \mathrm{mL}, \mathrm{CHCl}_{3}\right) .{ }^{1} \mathrm{H} \mathrm{NMR}\left(300 \mathrm{MHz}, \mathrm{CDCl}_{3}, \delta\right): 0.87$ $(\mathrm{s}, 6 \mathrm{H}), 1.22(\mathrm{~s}, 6 \mathrm{H}), 1.30-1.50(\mathrm{~m}, 4 \mathrm{H}), 1.70-1.95$ $(\mathrm{m}, 8 \mathrm{H}), 1.96-2.10(\mathrm{~m}, 4 \mathrm{H}), 2.40-2.65(\mathrm{~m}, 2 \mathrm{H})$, $3.64-3.74(\mathrm{~m}, 4 \mathrm{H}), 7.13(\mathrm{~s}, 2 \mathrm{H}) .{ }^{13} \mathrm{C}$ NMR $(75 \mathrm{MHz}$, $\left.\mathrm{CDCl}_{3}, \delta\right):$ 18.6, 20.2, 23.8, 24.1, 26.7, 35.0, 39.4, $40.9,42.7,74.5,86.2,122.8,153.0$. IR $(\nu, \mathrm{KBr}): 2952$, 2913, 2870, 1486, 1354, 1210, 1057, $1016 \mathrm{~cm}^{-1}$. MS $\mathrm{m} / \mathrm{z}$ (relative intensity): $634\left(\mathrm{M}^{+}, 80\right), 498(21), 362$ (81), 236 (9), 137 (47), 121 (9), 95 (36), 81 (100), 69 (65), 55(16). Elem. Anal. Calcd. for $\mathrm{C}_{26} \mathrm{H}_{36} \mathrm{I}_{2} \mathrm{O}_{2}$ : C, 49.23\%; H, 5.72\%. Found: C, 49.09: H, 5.61\%.

\section{$\mathrm{OHC}-\mathrm{Ar}-\mathrm{CHO}$}

5

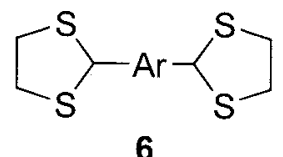

6

a $\mathrm{Ar}=1,3-\mathrm{C}_{6} \mathrm{H}_{4}$

b $\mathrm{Ar}=2,5-\mathrm{F}_{2}-1,4-\mathrm{C}_{6} \mathrm{H}_{2}$

$$
X-\operatorname{Ar}-X
$$

$7 \mathrm{X}=\mathrm{Br}$ or $\mathrm{I}$

a $\mathrm{Ar}=1,4-\mathrm{C}_{6} \mathrm{H}_{4}$

b $\mathrm{Ar}=1,3-\mathrm{C}_{6} \mathrm{H}_{4}$

c $\mathrm{Ar}=2,5-\mathrm{F}_{2}-1,4-\mathrm{C}_{6} \mathrm{H}_{2}$<smiles>N#Cc1cc(F)c(C#N)cc1F</smiles>

9

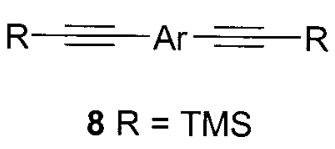

R'O<smiles>[R2]Oc1cc(C#[Al][Ca])c(O[R])cc1C</smiles><smiles>Oc1cc(I)c(O)cc1I</smiles>

10

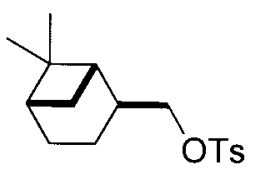

11 


\section{1,4-Diethynyl-2,5-dimyrtoxy-benzene (4d)}

To a stirred mixture of $\mathbf{7 d}(5.02 \mathrm{~g}, 7.9 \mathrm{mmol})$, CuI $(0.12 \mathrm{~g}, 0.64 \mathrm{mmol}), \mathrm{Pd}\left(\mathrm{PPh}_{3}\right)_{2} \mathrm{Cl}_{2}(0.28 \mathrm{~g}, 0.40$ $\mathrm{mmol}$ ), and $\mathrm{Et}_{3} \mathrm{~N}$ (3.5 mL, $\left.24.4 \mathrm{mmol}\right)$ in THF (15 $\mathrm{mL}$ ) was added dropwise a solution of trimethylsilyacetylene $(2.61 \mathrm{~mL}, 17.4 \mathrm{mmol})$ in THF (5 $\mathrm{mL}$ ). The mixture was stirred at room temperature for $4 \mathrm{~h}$, and the solid was filtered through silica gel. The filtrate was evaporated in vacuo to give $8 \mathbf{d}(4.2 \mathrm{~g}, 92 \%)$.

mp: $181-182{ }^{\circ} \mathrm{C}\left(\mathrm{CHCl}_{3} / \mathrm{CH}_{3} \mathrm{OH}\right) . \alpha_{\mathrm{D}}^{25}:-13.0(c$ $\left.0.05 \mathrm{~g} / \mathrm{mL}, \mathrm{CHCl}_{3}\right) .{ }^{1} \mathrm{H} \mathrm{NMR}\left(300 \mathrm{MHz}, \mathrm{CDCl}_{3}, \delta\right)$ : $0.23(\mathrm{~s}, 18 \mathrm{H}), 0.86(\mathrm{~s}, 6 \mathrm{H}), 1.22(\mathrm{~s}, 6 \mathrm{H}), 1.30-$ $1.45(\mathrm{~m}, 4 \mathrm{H}), 1.55-1.80(\mathrm{~m}, 8 \mathrm{H}), 1.81-1.95(\mathrm{~m}, 2$ $\mathrm{H}), 1.96-2.15$ (m, $2 \mathrm{H}), 2.40-2.60$ (m, $2 \mathrm{H}), 3.67$ $3.72(\mathrm{~m}, 4 \mathrm{H}), 6.85(\mathrm{~s}, 2 \mathrm{H}) .{ }^{13} \mathrm{C}$ NMR $(75 \mathrm{MHz}$, $\left.\mathrm{CDCl}_{3}, \delta\right): 0.0,18.1,20.2,23.6,24.1,26.7,35.1$, $39.3,40.9,42.6,72.9,100.0,101.1,113.7,116.8$, 154.1. IR ( $\nu, \mathrm{KBr}$ ): $2159 \mathrm{~cm}^{-1}$. MS $\mathrm{m} / z$ (relative intensity): 574. ELEM. ANAL. Calcd. for $\mathrm{C}_{36} \mathrm{H}_{54} \mathrm{O}_{2} \mathrm{Si}_{2}$ : C, $75.20 \%$; $\mathrm{H}, 9.47 \%$. Found: C, $75.56 \%$; H, $9.32 \%$.

To a stirred solution of $\mathbf{8 d}(3.38 \mathrm{~g}, 5.9 \mathrm{mmol})$ in THF (100 mL) were added $\mathrm{MeOH}(50 \mathrm{~mL})$ and a $20 \%$ aqueous $\mathrm{KOH}$ solution $(3.5 \mathrm{~mL})$ at room temperature. After being stirred for $2 \mathrm{~h}$, the mixture was filtered. The filtrate was extracted with $\mathrm{CH}_{2} \mathrm{Cl}_{2}$, and the organic layer was washed with water and brine and dried $\left(\mathrm{MgSO}_{4}\right)$. The solvent was removed in vacuo to give the residue, which was chromatographed on silica gel (EtOAc/hexane $=5: 95)$ to yield $\mathbf{4 d}(2.0 \mathrm{~g}, 79 \%)$.

mp: $103-105{ }^{\circ} \mathrm{C}\left(\mathrm{CHCl}_{3}-\mathrm{CH}_{3} \mathrm{OH}\right) . \alpha_{\mathrm{D}}^{25}:-8.0(c$ $\left.0.17 \mathrm{~g} / \mathrm{mL}, \mathrm{CHCl}_{3}\right) .{ }^{1} \mathrm{H} \mathrm{NMR}\left(300 \mathrm{MHz}, \mathrm{CDCl}_{3}, \delta\right)$ : $0.85(\mathrm{~s}, 6 \mathrm{H}), 1.21(\mathrm{~s}, 6 \mathrm{H}), 1.35-1.48(\mathrm{~m}, 4 \mathrm{H})$, $1.65-1,90(\mathrm{~m}, 8 \mathrm{H}), 1.90-2.02(\mathrm{~m}, 2 \mathrm{H}), 2.02-2.15$ $(\mathrm{m}, 2 \mathrm{H}), 2.40-2.55(\mathrm{~m}, 2 \mathrm{H}), 3.30(\mathrm{~s}, 2 \mathrm{H}), 3.66-$ $3.80(\mathrm{~m}, 4 \mathrm{H}), 6.91(\mathrm{~s}, 2 \mathrm{H}) .{ }^{13} \mathrm{C}$ NMR $(75 \mathrm{MHz}$, $\left.\mathrm{CDCl}_{3}, \delta\right): 18.3,20.1,23.6,24.0,26.6,34.8,39.2$, 40.8, 42.5, 73.6, 79.7, 82.4, 113.3, 117.8, 154.2. IR ( $\nu, \mathrm{KBr}): 3293,2110 \mathrm{~cm}^{-1}$. MS $\mathrm{m} / z: 430$. Elem. ANAL. Calcd. for $\mathrm{C}_{30} \mathrm{H}_{38} \mathrm{O}_{2}: \mathrm{C}, 83.68 \% ; \mathrm{H}, 8.89 \%$. Found: C, $83.68 \%$; H, $8.77 \%$.

\section{1,3-Bis-2-(dimethylstyrylsilanyl)vinylbenzene (2b)}

Under $\mathrm{N}_{2}$, a mixture of phenylacetylene $(112 \mathrm{mg}$, $1.1 \mathrm{mmol}), \quad 3 \mathbf{b}(123 \mathrm{mg}, \quad 0.5 \mathrm{mmol})$, and $\mathrm{RhCl}\left(\mathrm{PPh}_{3}\right)_{3}(1.0 \mathrm{mg}, 0.001 \mathrm{mmol})$ in $\mathrm{CH}_{2} \mathrm{Cl}_{2}(1$ $\mathrm{mL}$ ) was stirred at room temperature for $12 \mathrm{~h}$; the mixture was chromatographed on silica gel (hexane) to afford $\mathbf{2 b}$ as a colorless oil (202 $\mathrm{mg}, 86 \%$ ).

${ }^{1} \mathrm{H}$ NMR $\left(400 \mathrm{MHz}, \mathrm{CDCl}_{3}, \delta\right): 0.32(\mathrm{~s}, 12 \mathrm{H})$, $6.51(\mathrm{~d}, J=19.1 \mathrm{~Hz}, 2 \mathrm{H}), 6.54(\mathrm{~d}, J=19.1 \mathrm{~Hz}, 2$
$\mathrm{H}), 6.95(\mathrm{~d}, J=19.1 \mathrm{~Hz}, 4 \mathrm{H}), 7.10-7.50(\mathrm{~m}, 13$ $\mathrm{H}), 7.55(\mathrm{~s}, 1 \mathrm{H}) .{ }^{13} \mathrm{C} \mathrm{NMR}\left(75 \mathrm{MHz}, \mathrm{CDCl}_{3}, \delta\right)$ : $-2.6,124.5,126.2,126.4,127.3,127.7,128.1$, $128.5,128.7,138.2,138.4,144.7,144.9$. HRMS Calcd. for $\mathrm{C}_{30} \mathrm{H}_{34} \mathrm{Si}_{2}$ : 450.2199. Found: 450.2191 . Elem. Anal. Calcd. for $\mathrm{C}_{30} \mathrm{H}_{34} \mathrm{Si}_{2}$ : C, $79.94 \%$; $\mathrm{H}$, 7.60\%. Found: C, 79.97\%; H, 7.37\%.

\section{2,5-Difluoro-1,4-bis-2- (dimethylstyrylsilanyl)vinylbenzene (2c)}

To a solution of ( $\beta$-styryl)dimethylsilane ( $162 \mathrm{mg}$, $1.0 \mathrm{mmol})$ and $4 \mathbf{c}(81 \mathrm{mg}, 0.5 \mathrm{mmol})$ in THF (2 $\mathrm{mL}$ ) was added $\mathrm{RhCl}\left(\mathrm{PPh}_{3}\right)_{3}(2.3 \mathrm{mg})$, and the mixture was heated at $55-60{ }^{\circ} \mathrm{C}$ for $4.5 \mathrm{~h}$. The solvent was removed in vacuo to give the residue, which was chromatographed on silica gel (hexane) to afford 2c (102 mg, 42\%) as a colorless solid.

${ }^{1} \mathrm{H}$ NMR $\left(200 \mathrm{MHz}, \mathrm{CDCl}_{3}, \delta\right): 0.30(\mathrm{~s}, 12 \mathrm{H})$, $6.46(\mathrm{~d}, J=19.2 \mathrm{~Hz}, 2 \mathrm{H}), 6.56(\mathrm{~d}, J=19.2 \mathrm{~Hz}, 2$ $\mathrm{H}), 6.93(\mathrm{~d}, J=18.9 \mathrm{~Hz}, 2 \mathrm{H}), 7.06(\mathrm{~d}, J=18.9 \mathrm{~Hz}$, $2 \mathrm{H}), 7.19(\mathrm{t}, J=8.7 \mathrm{~Hz}, 2 \mathrm{H}), 7.27-7.50(\mathrm{~m}, 12 \mathrm{H})$. ${ }^{13} \mathrm{C}$ NMR $\left(75 \mathrm{MHz}, \mathrm{CDCl}_{3}, \delta\right):-2.7,113.0(\mathrm{dd}, J$ $=17.27 \mathrm{~Hz}), 126.7(\mathrm{~m}), 127.2,128.2(\mathrm{~m}), 131.9$, $135.2(\mathrm{~m}), 138.1(\mathrm{~m}), 144.3,145.2,156.3(\mathrm{dd}, J$ $=4.4,246 \mathrm{~Hz}$ ). HRMS Calcd. for $\mathrm{C}_{30} \mathrm{H}_{32} \mathrm{~F}_{2} \mathrm{Si}_{2}$ : 486.2010. Found 486.2018.

\section{2,5-Bis(dimethylstyrylsilanyl)vinyl-1,4- dimyrtoxybenzene (2d)}

A mixture of ( $\beta$-styryl)dimethylsilane $(320 \mathrm{mg}$, $2.3 \mathrm{mmol}), 4 \mathrm{dd}(446 \mathrm{mg}, 1.0 \mathrm{mmol})$, and $\mathrm{RhCl}\left(\mathrm{PPh}_{3}\right)_{3}(1.5 \mathrm{mg}, 0.0016 \mathrm{mmol})$ in $\mathrm{CH}_{2} \mathrm{Cl}_{2}$ $(1.5 \mathrm{~mL})$ was stirred under $\mathrm{N}_{2}$ at room temperature for $12 \mathrm{~h}$. After the removal of the solvent, the residue was chromatographed on silica gel $($ EtOAc/hexane $=3: 97)$ to afford 2d $(380 \mathrm{mg}$, $50 \%)$.

mp: $103-104{ }^{\circ} \mathrm{C} . \alpha_{\mathrm{D}}^{25}:-11\left(\right.$ c $\left.0.1 \mathrm{~g} / \mathrm{mL}, \mathrm{CHCl}_{3}\right)$. ${ }^{1} \mathrm{H}$ NMR $\left(\mathrm{CDCl}_{3}, 200 \mathrm{MHz}, \delta\right): 0.31(\mathrm{~s}, 12 \mathrm{H}), 0.83$ (s, $6 \mathrm{H}), 1.19(\mathrm{~s}, 6 \mathrm{H}), 1.30-1.48(\mathrm{~m} .2 \mathrm{H}), 1.60-$ $1.80(\mathrm{~m}, 8 \mathrm{H}), 1.80-1.93(\mathrm{~m}, 2 \mathrm{H}), 1.95-2.12(\mathrm{~m}, 2$ $\mathrm{H}), 2.40-2.60(\mathrm{~m}, 2 \mathrm{H}), 3.74(\mathrm{~m}, 4 \mathrm{H}), 6.44(\mathrm{~d}, J$ $=19.2 \mathrm{~Hz}, 2 \mathrm{H}), 6.51(\mathrm{~d}, J=19.1 \mathrm{~Hz}, 2 \mathrm{H}), 6.94(\mathrm{~d}$, $J=19.1 \mathrm{~Hz}, 2 \mathrm{H}), 7.01(\mathrm{~s}, 2 \mathrm{H}), 7.18-7.48(\mathrm{~m}, 12$ H). ${ }^{13} \mathrm{C} \mathrm{NMR}\left(\mathrm{CDCl}_{3}, 75 \mathrm{MHz}, \delta\right): 18.5,20.2,23.7$, $14.1,16.7,35.3,39.3,40.9,42.9,73.4,110.3$, $126.4,127.4,128.0,128.1,128.5,138.3,139.1$, 144.8, 151.0. MS m/z: 754. Elem. Anal. Calcd. for $\mathrm{C}_{50} \mathrm{H}_{66} \mathrm{O}_{2} \mathrm{Si}_{2}$ : C, 79.52\%; H, 8.81\%. Found: $\mathrm{C}$, $79.52 \%$; $\mathrm{H}, 8.24 \%$. 


\section{Polymer 1b}

A mixture of $4 \mathrm{~b}(65.6 \mathrm{mg}, 0.52 \mathrm{mmol}), 3 \mathrm{~b}(128 \mathrm{mg}$, $0.52 \mathrm{mmol})$, and $\mathrm{RhCl}\left(\mathrm{PPh}_{3}\right)_{3}(1.1 \mathrm{mg}, 0.0012$ mmol) in $\mathrm{CH}_{2} \mathrm{Cl}_{2}(0.5 \mathrm{~mL})$ was refluxed under $\mathrm{N}_{2}$ for $4 \mathrm{~h}$. After the mixture cooled, $\mathrm{MeOH}$ was added to precipitate crude $\mathbf{1 b}$, which was dissolved in $\mathrm{CH}_{2} \mathrm{Cl}_{2}$ and reprecipitated with $\mathrm{MeOH}$. After filtration, the solid was washed with $\mathrm{MeOH}$ and dried to give $\mathbf{1 b}(121 \mathrm{mg}, 63 \%)$.

${ }^{1} \mathrm{H} \mathrm{NMR}\left(300 \mathrm{MHz}, \mathrm{CDCl}_{3}, \delta\right): 0.32(\mathrm{br} \mathrm{s}, 12 \mathrm{H})$, 6.55 (br d, $J=18.9 \mathrm{~Hz}, 4 \mathrm{H}$ ), 6.95 (br d, $J=18.9$ $\mathrm{Hz}, 4 \mathrm{H}$ ), 7.20-7.60 (br m, $8 \mathrm{H}$ ). $M_{\mathrm{n}}$ : 3000 [polydispersity index $(\mathrm{PDI})=2.65]$. Elem. Anal. Calcd. for $\mathrm{C}_{24} \mathrm{H}_{28} \mathrm{Si}_{2}: \mathrm{C}, 77.35, \mathrm{H}, 7.57 \%$. Found: $\mathrm{C}$, 78.24, H, 7.44\%.

\section{Polymer 1c}

A mixture of $4 \mathbf{a}(63 \mathrm{mg}, 0.52 \mathrm{mmol}), 3 \mathbf{b}(123 \mathrm{mg}$, $0.50 \mathrm{mmol}$ ), and $\mathrm{RhCl}\left(\mathrm{PPh}_{3}\right)_{3}(1.0 \mathrm{mg}, 0.001$ mmol) in $\mathrm{CH}_{2} \mathrm{Cl}_{2}(1.0 \mathrm{~mL})$ was refluxed under $\mathrm{N}_{2}$ for $8 \mathrm{~h}$. After a workup in a manner similar to that described previously, 1c was obtained (155 $\mathrm{mg}, 83 \%)$.

${ }^{1} \mathrm{H}$ NMR (300 MHz, $\mathrm{CDCl}_{3}, \delta$ ): $0.32(\mathrm{br} \mathrm{s}, 12 \mathrm{H})$, 6.53 (br d, $J=18.7 \mathrm{~Hz}, 4 \mathrm{H}$ ), 6.93 (br d, $J=18.7$ $\mathrm{Hz}, 4 \mathrm{H}$ ), 7.10-7.60 (br m, $8 \mathrm{H}$ ). Elem. Anal. Calcd. for $\mathrm{C}_{24} \mathrm{H}_{28} \mathrm{Si}_{2}$ : C, 77.35, H, 7.57\%. Found: C, 78.90, H, 6.43\%.

For $0.05 \mathrm{M} \mathrm{RhCl}\left(\mathrm{PPh}_{3}\right)_{3}$, the time was $24 \mathrm{~h}$, the temperature was $25{ }^{\circ} \mathrm{C}$, the yield was $85 \%, M_{\mathrm{n}}$ was 2200, and DPI was 2.8. For $0.1 \mathrm{M}$ $\mathrm{RhCl}\left(\mathrm{PPh}_{3}\right)_{3}$, the time was $8 \mathrm{~h}$, the temperature was $50{ }^{\circ} \mathrm{C}$, the yield was $83 \%, M_{\mathrm{n}}$ was 3500 , and DPI was 3.6. For $1.0 \mathrm{M} \mathrm{RhCl}\left(\mathrm{PPh}_{3}\right)_{3}$, the time was $8 \mathrm{~h}$, the temperature was $50{ }^{\circ} \mathrm{C}$, the yield was $80 \%, M_{\mathrm{n}}$ was 6200 , and DPI was 4.7 .

\begin{tabular}{lrcccc}
\hline $\begin{array}{l}\mathrm{RhCI}\left(\mathrm{PPh}_{3}\right)_{3} \\
(\mathrm{M})\end{array}$ & $\begin{array}{c}\text { Time } \\
(\mathrm{H})\end{array}$ & $\begin{array}{c}\text { Temp } \\
\left({ }^{\circ}(\mathrm{C})\right.\end{array}$ & $\%$ Yield & $\mathrm{M}_{\mathrm{n}}$ & DPI \\
\hline & & & & & \\
0.05 & 24 & 25 & 84 & 2,200 & 2.8 \\
0.1 & 8 & 50 & 83 & 3,500 & 3.6 \\
1.0 & 8 & 50 & 80 & 6,200 & 4.7 \\
\hline
\end{tabular}

\section{Polymer 1d}

In a manner similar to that described previously, a mixture of $4 \mathbf{c}(16 \mathrm{mg}, 0.1 \mathrm{mmol}), 3 \mathbf{c}(28 \mathrm{mg}, 0.1$ $\mathrm{mmol})$, and $\mathrm{RhCl}\left(\mathrm{PPh}_{3}\right)_{3}(1.5 \mathrm{mg}, 0.0015 \mathrm{mmol})$ in THF $(0.7 \mathrm{~mL})$ was heated under $\mathrm{N}_{2}$ to $55-60{ }^{\circ} \mathrm{C}$ for $6 \mathrm{~h}$. After the workup, 1d was obtained (9.3 $\mathrm{mg}, 21 \%)$.
${ }^{1} \mathrm{H}$ NMR (200 MHz, $\left.\mathrm{CDCl}_{3}, \delta\right): 0.30$ (br s, $\left.6 \mathrm{H}\right)$, $6.51(\mathrm{~d}, J=19 \mathrm{~Hz}, 2 \mathrm{H}), 7.05(\mathrm{~d}, J=18 \mathrm{~Hz}, 2 \mathrm{H})$, 7.15 (t, $J=8 \mathrm{~Hz}, 2 \mathrm{H}$ ). Elem. Anal. Calcd. for $\mathrm{C}_{12} \mathrm{H}_{12} \mathrm{Si} \mathrm{C}, 64.82 \%$; H, 5.44\%. Found C, $64.00 \%$; $\mathrm{H}, 6.13 \%$.

For $0.2 \mathrm{M} \mathrm{RhCl}\left(\mathrm{PPh}_{3}\right)_{3}$, there were two sets of conditions: (1) the time was $3 \mathrm{~h}$, the temperature was $50{ }^{\circ} \mathrm{C}$, the yield was $49 \%, M_{\mathrm{n}}$ was 1800 , and DPI was 1.6, and (2) the time was $6 \mathrm{~h}$, the temperature was $57-60{ }^{\circ} \mathrm{C}$, the yield was $21 \%, M_{\mathrm{n}}$ was 4800 , and DPI was 2.7 .

\begin{tabular}{cccccc}
\hline $\begin{array}{c}\mathrm{RhCI}\left(\mathrm{PPh}_{3}\right)_{3} \\
(\mathrm{M})\end{array}$ & $\begin{array}{c}\text { Time } \\
(\mathrm{H})\end{array}$ & $\begin{array}{c}\text { Temp } \\
\left({ }^{\circ}(\mathrm{C})\right.\end{array}$ & $\%$ Yield & $\mathrm{M}_{\mathrm{n}}$ & DPI \\
\hline 0.2 & 3 & 50 & 49 & 1,800 & 1.6 \\
0.2 & 6 & $55-60$ & 21 & 4,800 & 2.7 \\
\hline
\end{tabular}

\section{Polymer 1f}

To a solution of $4 \mathbf{e}(0.45 \mathrm{~g}, 1.0 \mathrm{mmol})$ and $\mathbf{3 a}(0.25$ g $1.0 \mathrm{mmol})$ in THF (5 mL) was added $\mathrm{Rh}\left(\mathrm{PPh}_{3}\right)_{3} \mathrm{Cl}$ (4.6 mg, $0.005 \mathrm{mmol}$ ) under $\mathrm{N}_{2}$. The mixture was refluxed for $10 \mathrm{~h}$. After cooling to room temperature, the mixture was poured into $\mathrm{CH}_{3} \mathrm{OH}$ to precipitate the crude 1f. The precipitate was collected and redissolved in THF and then precipitated again with $\mathrm{CH}_{3} \mathrm{OH}$. Polymer $1 \mathbf{f}$ was collected by filtration and washed with $\mathrm{CH}_{3} \mathrm{OH}(0.49 \mathrm{~g}, 70 \%)$.

$M_{\mathrm{n}}: 15,900(\mathrm{PDI}=2.2) .{ }^{1} \mathrm{H}$ NMR $(300 \mathrm{MHz}$, $\left.\mathrm{CDCl}_{3}, \delta\right): 0.3(\mathrm{br} \mathrm{s}, 12 \mathrm{H}), 0.84(\mathrm{br} \mathrm{s}, 6 \mathrm{H}), 1.19$ (br $\mathrm{s}, 6 \mathrm{H}), 1.3-2.75(\mathrm{~m}, 16 \mathrm{H}), 3.25-4.1(\mathrm{~m}, 4 \mathrm{H})$, 6.2-6.7 (m, $4 \mathrm{H}), 6.7-7.2(\mathrm{~m}, 6 \mathrm{H}), 7.25-7.6(\mathrm{~m}, 4$ $\mathrm{H}$ ). Elem. Anal. Calcd. for $\mathrm{C}_{44} \mathrm{H}_{60} \mathrm{O}_{2} \mathrm{Si}_{2}$ : C, $78.05 \%$; H, 8.93\%. Found: C, 77.76\%; H, 8.55\%.

\section{Time-Resolved Fluorescence and Quantum Yield Measurements}

Compound $2\left(10^{-5}\right.$ to $\left.10^{-6} \mathrm{M}\right)$ or polymer $1\left(10^{-3}\right.$ to $10^{-4} \mathrm{~g} / \mathrm{L}$ ) was dissolved in $\mathrm{CHCl}_{3}$ (spectroscopic grade), and the solution was subjected to photophysical measurements. The quantum yield was calculated with reference to standard quinine sulfate dihydrate in $0.1 \mathrm{~N} \mathrm{H}_{2} \mathrm{SO}_{4}(\Phi=0.546)$ or coumarin 1 in EtOAc $(\Phi=0.99)$. The excitation spectra of polymer 1 were monitored at the wavelengths specified. The fluorescence decay curves and time-resolved fluorescence were measured with a picosecond-correlated single-photon-counting apparatus equipped with a second harmonic of a mode-locked $\mathrm{Nd}^{3+}$ :/YAG laser (I-400, coher- 
ent). The excitation wavelength was based on the absorption $\lambda_{\max }$. The exponential fittings were simulated by the equation $y=y_{0}+A_{1} \exp \left(x_{0}\right.$ $-x) t_{1}+A_{2} \exp \left(x_{0}-x\right) t_{2}$ from time-resolved fluorescence spectra.

The authors thank the Ministry of Education, Academia Sinica, and the National Science Council of the Republic of China for their support.

\section{REFERENCES AND NOTES}

1. Hu, S. S.; Weber, W. P. Polym Bull 1989, 21.

2. Corriu, R. J. P.; Guerin, C.; Henner, B.; Kuhlmann, T.; Jean, A.; Garnier, F.; Yassar, A. Chem Mater $1990,2,351$.

3. Ohshita, J.; Kanaya, D.; Ishikawa, M.; Koike, T.; Yamanaka, T. Macromolecules 1991, 24, 2106.

4. Wu, H. J.; Interrante, L. V. Macromolecules 1992, 25,1840

5. Pang, Y.; Ijadi-Maghsoodi, S.; Barton, T. J. Macromolecules 1993, 26, 5671.

6. Malliaras, G. G.; Herrema, J. K.; Wildeman, J.; Wieringa, R. H.; Gill, R. E.; Lampoura, S. S.; Hadziioannou, G. Adv Mater 1993, 5, 721.

7. Yuan, C.-H.; West, R. Appl Organomet Chem 1994 $8,423$.

8. Najchrzak, M.; Itami, Y.; Marciniec, B.; Pawluc, P. Macromol Rapid Commun 2001, 22, 202.

9. Kim, H. K.; Ryu, M.-K.; Lee, S.-M. Macromolecules 1997, 30, 1236.

10. Miao, Y.-J.; Bazan, G. C. Macromolecules 1997, 30, 7414.

11. Kim, H. K.; Ryu, M. K.; Kim, K. D.; Lee, S. M.; Cho, S. W.; Park, J. W. Macromolecules 1998, 31, 1114

12. Jung, S. H.; Kim, H. K.; Kim, S. H.; Kim, Y. H.; Jeoung, S. C.; Kim, D. Macromolecules 2000, 33, 9277.

13. Son, D. Y.; Bucca, D.; Keller, T. M. Tetrahedron Lett 1996, 37, 1579.

14. Mori, A.; Takahisa, E.; Kajiro, H.; Nishihara, Y.; Hiyama, T. Macromolecules 2000, 33, 1115.

15. Kunai, A.; Toyoda, E.; Nagamoto, I.; Horio, T.; Ishikawa, M. Organometallics 1996, 15, 75.

16. Li, H.; West, R. Macromolecules 1998, 31, 2866.

17. Oshita, J.; Takada, A.; Kunai, A.; Komaguchi, K.; Shiotani, M.; Adachi, A.; Sakamaki, K.; Okita, K.; Harima, Y.; Konugi, Y.; Yamashita, K.; Ishikawa, M. Organometallics 2000, 19, 4492

18. Kwak, G.; Masuda, T. J Polym Sci Part A: Polym Chem 2002, 40, 535.

19. Gao, Z.; Lee, C. S.; Bello, I.; Lee, S. T.; Chen, R.-M.; Luh, T.-Y.; J, Shi.; Tang, C. W. Appl Phys Lett 1999, 74, 865.

20. Chen, R.-M.; Deng, Z.; Lee, S. T.; Luh, T.-Y. In Semiconductive Polymers; Hsieh, B. R.; Galvin, M.;
Wei, Y., Eds.; ACS Symposium Series; American Chemical Society: Washington, DC, 1999; Vol. 735, Chapter 23, pp 374-383.

21. Luh, T.-Y.; Chen, R.-M.; Hwu, T.-Y.; Basu, S.; Shiau, C.-W.; Lin, W.-Y.; Jin, B.-Y.; Hsu, C. C. Pure Appl Chem 2001, 73, 243.

22. Cheng, Y.-J.; Hwu, T.-Y.; Hsu, J.-H.; Luh, T.-Y. Chem Commun 2002, 1978 .

23. Chen, R.-M.; Chien, K.-M.; Wong, K.-T.; Jin, B.-Y.; Luh, T.-Y.; Hsu, J.-H.; Fann, W. J Am Chem Soc 1997, 119, 11321.

24. Hu, D. H.; Yu, J.; Wong, K.; Bagchi, B.; Rossky, P. J.; Barbara, P. F. Nature 2000, 405, 1030 and references therein.

25. Grosberg, A. Y.; Kuznetsov, D. V. Macromolecules 1992, 25, 1970.

26. Ivanov, V. A.; Paul, W.; Binder, K. J Chem Phys 1998, 109, 5659.

27. Noguchi, H.; Yoshikawa, K. J Chem Phys 1998, 109, 5070.

28. Kuznetsov, Y. A.; Timoshenko, E. G. J Chem Phys 1999, 111, 3744.

29. Becker, H.; Spreitzer, H.; Kreuder, W.; Kluge, E.; Schenk, H.; Parker, I.; Cao, Y. Adv Mater 2000, 12, 42.

30. Wong, K. F.; Skaf, M. S.; Yang, C. Y.; Rossky, P. J.; Bagchi, B.; Hu, D. H.; Yu, J.; Barbara, P. F. J Phys Chem B 2001, 105, 6103.

31. Bazan, G. C.; Oldham, W. J.; Lachicotte, R. J.; Tretiak, S.; Chernyak, V.; Mukamel, S. J Am Chem Soc 1998, 120, 9188.

32. Wang, S. J.; Bazan, G. C.; Tretiak, S.; Mukamel, S. J Am Chem Soc 2000, 122, 1289.

33. Bartholomew, G. P.; Barzan, G. C. Acc Chem Res $2001,34,30$.

34. Ojima, I. In The Chemistry of Organosilicon Compounds; Rappoport, Z.; Apeloig, Y., Eds.; Wiley: Chichester, England, 1997; Vol. 2, Chapter 29.

35. Ni, Z.-J.; Yang, P.-F.; Ng, D. K. P.; Tzeng, Y.-L.; Luh, T.-Y. J Am Chem Soc 1990, 112, 9356.

36. Luh, T.-Y. Acc Chem Res 1991, 24, 257.

37. Luh, T.-Y. Pure Appl Chem 1996, 68, 105.

38. Chen, R.-M.; Luh, T.-Y. Tetrahedron 1998, 54, 1197.

39. Takahashi, S.; Kuroyama, Y.; Sonogashira, K.; Hagihara, N. Synthesis 1980, 627.

40. Bredas, J. L.; Cornil, J.; Beljonne, D.; dos Santos, D. A.; Shuai, Z. G. Acc Chem Res 1999, 32, 267.

41. Cornil, J.; dos Santos, D. A.; Crispin, A. X.; Silbey, R.; Bredas, J. L. J Am Chem Soc 1998, 120, 1289 and references therein.

42. Siddiqui, S.; Spano, F. C. Chem Phys Lett 1999 , 308,99 .

43. Spano, F. C.; Siddiqui, S. Chem Phys Lett 1999 , $314,481$.

44. Cornil, J.; Beljonne, D.; Calbert, J. P.; Bredas, J. L. Adv Mater 2001, 13, 1053.

45. Ponzini, F.; Zagha, R.; Hardcastle, K.; Siegel, J. S. Angew Chem Int Ed 2000, 39, 2323. 